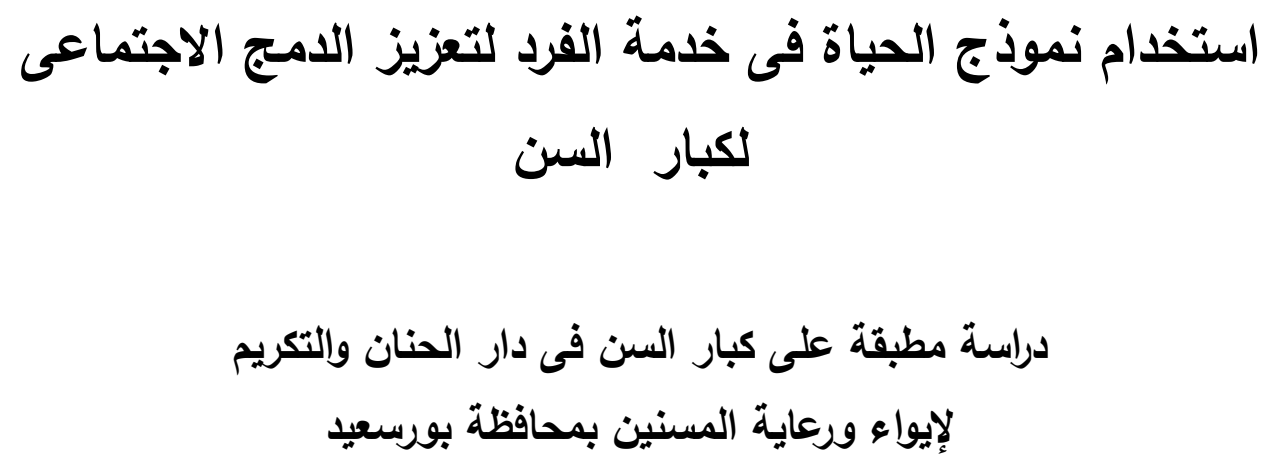

Use the life model in social casework to enhance the social inclusion for the elderly

An applied study to the elderly in Dar Al Hanan and honoring to accommodate and care for the elderly In Port Said Governorate

$$
\begin{aligned}
& \text { اعداد } \\
& \text { د/ داليا نعيم عبد الوهاب شلبى الود } \\
& \text { مدرس خدمة الفرد } \\
& \text { بالمعه العالي للخدمة الاجتماعية } \\
& \text { ببورسعيا }
\end{aligned}
$$


مجلة كلية الخدمة الاجتماعية للار اسات و البحوث الاجتماعية - جامعة الفيوم 
ملخص

استخدام نموذج الحياة فى خدمة الفرد لتعزيز الامج الاجتماعى لكبار السن دراسة مطبةة على كبار السن فى دار الحنان والتكريم لإيواء ورعاية المسنين بمحافظة بورسعيد

مشكلة الدراسة:

استخدام نموذج الحياة فى خدمة الفرد لتعزيز الدمج الاجتماعى لكبار السن المقيمين بدور الايواء. أهداف الاراسةة:

اختبار فعالية برنامج التدخل المهنى باستخدام نموذج الحياة فى خدمة الفرد لتعزيز الدمج الاجتماعى لكبار السن المقيمين بدور الايواء فى محيط الأسرة- وفى المؤسسة- وفى المجتمع. مفاهيم الدراسة: نموذج الحياة- الدمج الاجتماعى - كبار السن. نوع الدراسة والمنهج المستخدم:

تتنمى هذه الدراسة إلى نمط الدراسات شبه التجريبية التى تعتمد على المنهج التجريبى لاختبار العلاقة بين متغير مستقل وهو نموذج الحياة فى خدمة الفرد ومتغير تابع وهو تعزيز الدمج الاجتماعى لكبار السن المقيمين بدور الايواء. فروض الدراسة: الفرض الرئيسى : توجد علاقة ايجابية دالة احصائياً بين استخدام نموذج الحياة فى خدمة الفرد وتعزيز الدمج الاجتماعى لكبار السن. أدوات الدراسةة:

مقياس الدمج الاجتماعى لكبار السن (إعداد الباحثة)، والأدوات المساعدة مثل المجالات والوثائق التى نبين إحصاءات المسنين بالدار ، والبيانات المعرفة. أهم نتائج الاراسةة: أثنتت نتائج الدراسة صحة الفرض الرئيسى. كلمات (فتثاحية: نموذج الحياة فى خدمة الفرد - الدمج الاجتماعى - كبار السن - دور الايواء 
Use the life model in social casework to enhance the social inclusion for the elderly

An applied study to the elderly in Dar Al Hanan and honoring to accommodate and care for the elderly

In Port Said Governorate

The study Problem:

Using the life model in social casework to enhance the social inclusion of the elderly residing in the accommodation.

The study aim :

Test the effectiveness of a professional intervention program using the life model in social casework to enhance the social inclusion of the elderly residing in shelters in the family - and in the institution - and in society.

\section{Study concepts:}

The life model - social inclusion - the elderly.

Type of study and method used:

This study belongs to the pattern of quasi-experimental studies that rely on the experimental approach to test the relationship between an independent variable, which is the life model in social casework and a dependent variable, which is the enhancement of social inclusion of the elderly residing in the shelter role.

Hypotheses of study:

The main hypothesis: There is a positive relationship statistically between the use of the life model in social casework and the promotion of social inclusion of the elderly.

Study tools: 
The scale of social inclusion for the elderly (researcher preparation), and auxiliary tools such as reports and documents that show the statistics of the elderly in the house, and data defined.

The most important results of the study:

The results of the study proved the validity of the main hypothesis.

Key words:

The life model in social casework - social inclusion - the elderly - shelters 
أولاً: مقدمة تؤدى إلى مشكلة الدراسة: سـتبقى رعاية كبار السـن تأخذ أهمية خاصـة لاسـيما فى الهتمعات العربية والاسـلامية التى تتميز

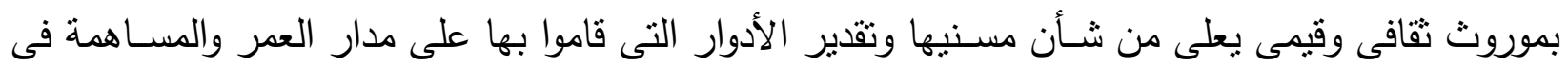

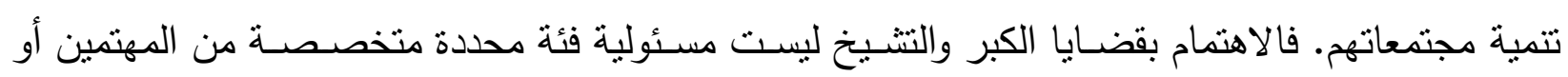
المتخصصين، بل هى مسئولية المجتمع بجميع طوائفه، وبقدر تزايد الوعى ومواجهة الثورة الديموجرافية بشكل

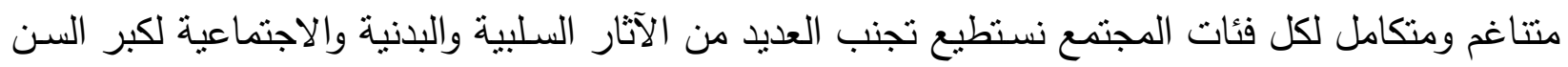

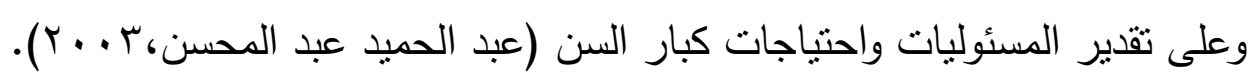

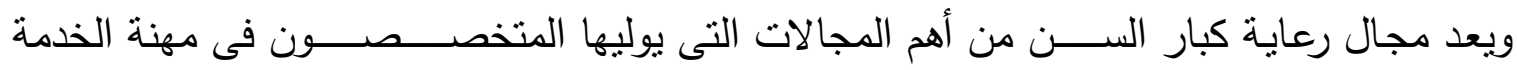

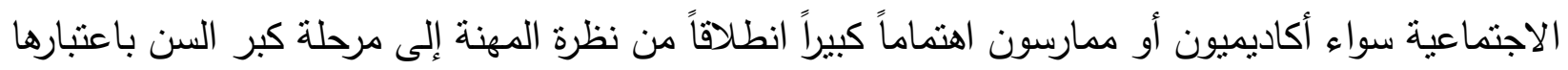

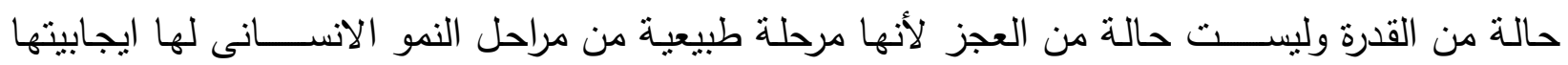
وعطاءها، واعترافا بأن مؤسسات رعاية كبار السن ذات أهمية اجتماعية تنعى إلى تحقيقها فى إطار تكاملها

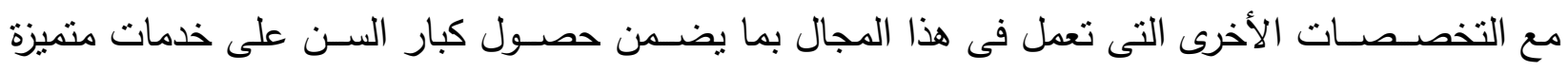
وظروف معيشية أفضل فى ظل الظروف والمتغيرات السريعة والمتلاحقة المؤثرة على وضع المسنين وطبيعة ما يقدم لهم من خدمات أسرية وأهلية وحكومية. ويعانى الكثير من كبار السـن العديد من المشـكلات الاجتماعية والنفسـية والاقتصـادية والعاطفية والأسرية التى تقلل من فرص الاندماج الاجتماعى لديهم سواء على مستوى الأسرة أو المؤسسات المتخصصة

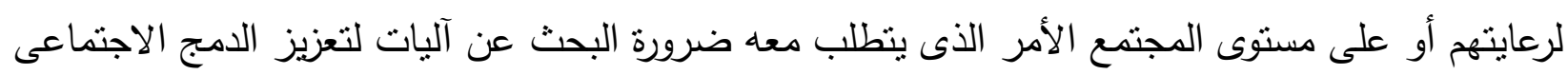

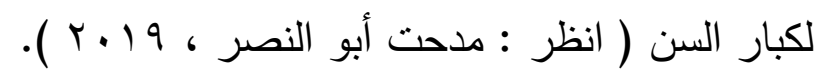

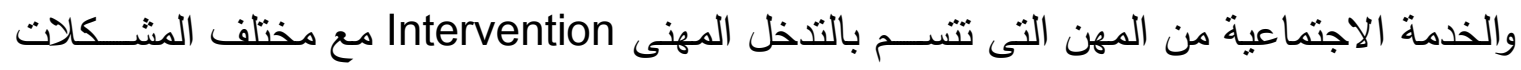
التى تواجه الأفراد والجماعات والأســر والمجتمعات، فهى تتعامل مع قطاع كبار الســن بطرقها وأســاليبها المختلفة من أجل الوصول إلى مستوى أفضل يستطيع كبار السن من خلاله أن يشبعوا احتباجاتهم ويواجهون

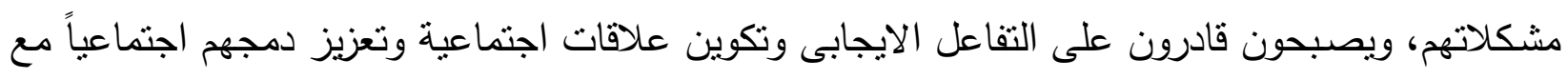
الآخرين.

فمهنة الخدمة الاجتماعية مطالبة بالتثخل مع مشكلات كبار السن والعمل على الحفاظ على كرامتهم ومواجهة العوائق الاجتماعية التى تقيد حركتهم وتحرمهم من ممارســــة حياتهم الطبيعية وتعزز من دمجهم اجتماعياً فى محيط أسرهم، أو المؤسسات المخصصة لرعايتهم أو فى محيط المجتمع الذى يعيشون فيه. 
وتعد طريقة العمل مع الأفراد إحدى طرق مهنة الخدمة الاجتماعية والتى تمارس على نطاق واســـع فى مختلف المؤسسـات وخاصـة مؤسسـات رعاية كبار السـ، وذلك لما تتمتع به هذه الطريقة من العديد من النماذج والمداخل والاتجاهات العلاجية الحديثة والمعاصـــرة والتى تمكنها من التعامل مع فئة كبار الســن وتتصدى للمشكلات التى تصاحب هذه الفئة وتسعى لاشباع احتياجاتها المختلفة من بينها الحاجة إلى الدمج الاجتماعى مع الآخرين.

ونموذج الحياة The Life Model أحد نماذج الممارسـة المهنية فى مهنة الخدمة الاجتماعية ويركز هذا النموذج على التفاعل بين الانســان والبيئة، ويهنم هذا النموذج بحياة الانســـان ومراحل نموه والحاجات المطلوب إثـــباعها فى كل مرحلة والمشــكلات التى قد تواجه الانســان عندما ينتقل من مرحلة إلى أخرى

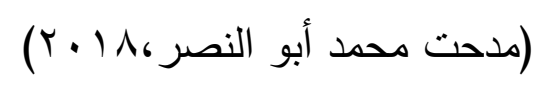

ونموذج الحياة Life Model هو أحد النماذج العلاجية الحديثة فى الخدمة الاجتماعية عامة وطربقة العمل مع الأفراد خاصــة والذى يمكن الاعتماد على معطياته فى تعزيز الدمج الاجتماعى لكبار السـن سـواء داخل أسرهم أو داخل المؤسسات المخصصة لرعايتهم أو فى المجتمع. لذا تتحدد الدراسـة الراهنة فى: اسـتخدام نموذج الحياة فى خدمة الفرد لتعزيز الدمج الاجتماعى لكبار

$$
\text { ثانياً: أهمية المقيمين بدور الايواء. }
$$

ا- اتفاق العديد من البحوث والدراسـات العلمية السـابقة على أهمية وضـرورة رعاية كبار السـن وما

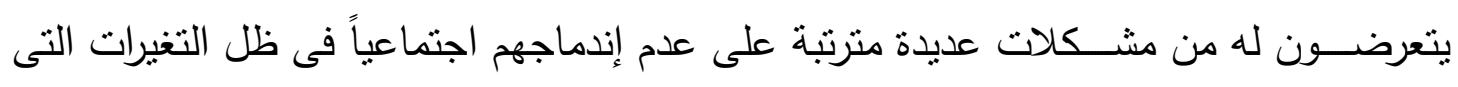

$$
\text { طرأت على المجتمع المصرى. }
$$

ץ- قد تسهم هذه الدراسـة فى تحسين اسلوب حياة كبار السن اجتماعياً داخل مؤسسـات دور الايواء

$$
\text { ومع أسرهم والمجتمع. }
$$

ب- الزيادة المضــطردة فى أعداد ونسـب كبار السـن فى السـنوات الأخيرة الأمر الذى يتطلب معه

الاهتمام بقضايا هذه الفئة بإعتبارها قضايا قومية.

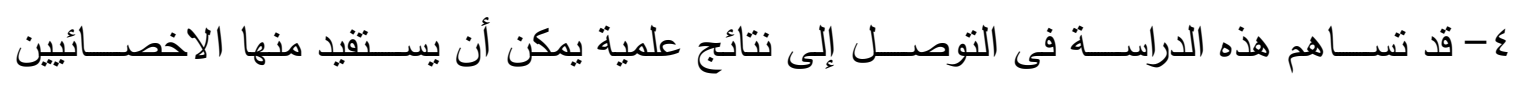
الاجتماعيين العاملين فى مؤسسات وجمعيات ايواء ورعاية كبار السن فى المجتمع المصرى.

ثالثاً: أهداف الدراسةة:

تستهدف الدراسة الحالية تحقيق الأهداف التالية: 


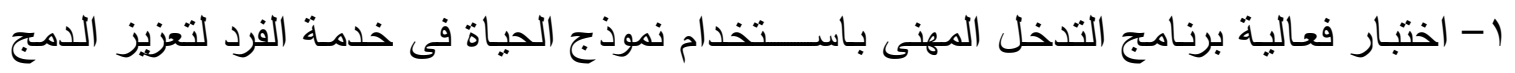

$$
\text { الاجتماعى لكبار السن المقيمين بدور الايواء. }
$$

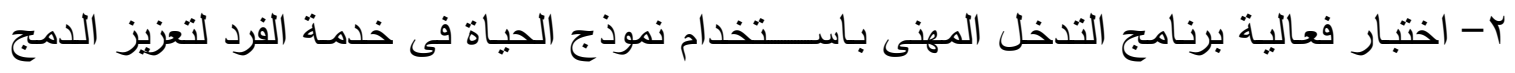

$$
\text { الاجتماعى لكبار السن فى محبط الأسرة. }
$$

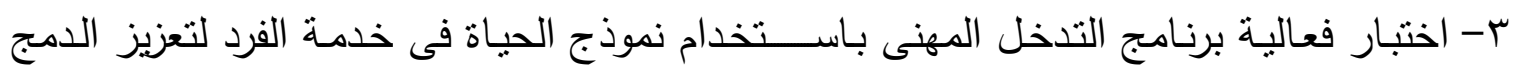

$$
\text { الاجتماعى لكبار السن فى مؤسسة الايواء. }
$$

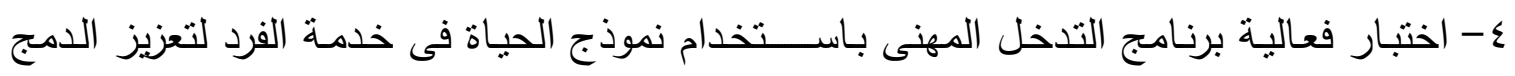

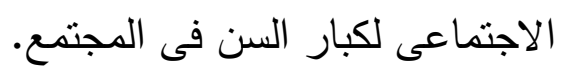

رابعاً: مفاهيم الاراسة: الاستاعى

ا - نموذج الحياة: The Life Model

يعتبر العالم والمحلل النفسـى "باندلر Bandler" هو أول من قام باســخدام مصـطلح نموذج الحياة

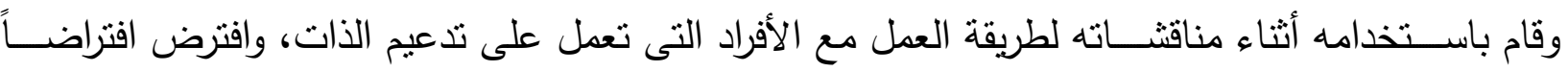

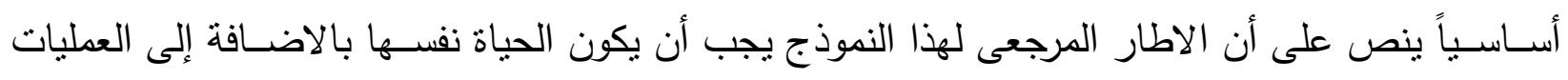

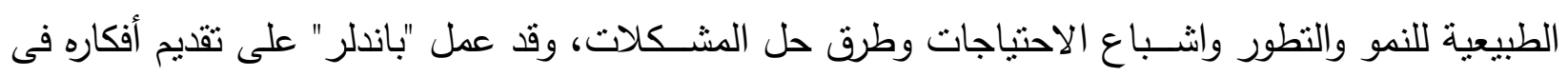
صورة مفاهيم مشتقة من مظور الدخل الايكولوجى (Germain B Calel,1995). ويعتمد النموذج على المدخل النظرى المتعدد ويعتمد فى خدمة الفرد على اســتراتيجية علاجية ولكن التهن

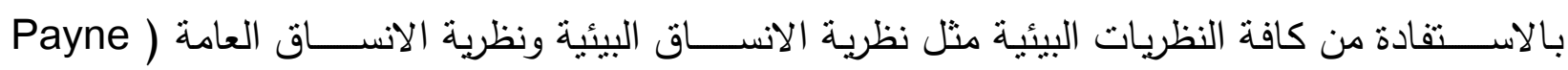
.(Maleon, 1997

ويشـــار إلى نموذج الحياة على أنه اســلوب فى ممارســـة الخدمة الاجتماعية يســتخدم المنظور

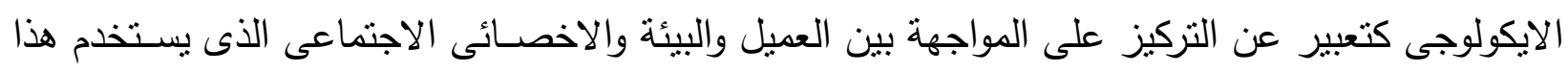
السلوب يركز على المشاكل فى الحياة (التحولات فى الحياة، التفاعلات بين الأفراد، والمعوقات البيئية). وبذلك فإن نموذج الحياة يســتخدم مع النوعيات المختلفة من المشــكلات والمراحل العمرية المختلفة للعملاء، وفى مواقف ومشكلات ومجالات عديدة فى مجالات ممارسة خدمة الفرد (سامية همام،ب . . ب).

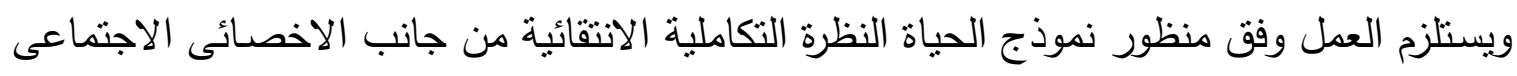
حتى يسنطيع إحداث التوازن المطلوب وتعزيز الدمج الاجنماعى لكبار السن.

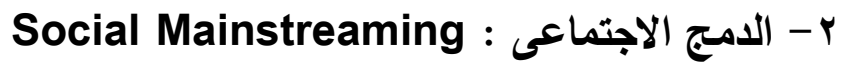


يثـير مصـطلح الدمج إلى تحقيق المسـاواة والمشـاركة وإتاحة الفرص لكبار السـن اسـوة بأقرانهم فى المجتمع وإزالة أى مظهر من مظاهر التمبيز تجاههم، فمفهوم الدمج فى جوهره مفهوم اجتماعى أخلاقى نابع من حركة حقوق الانسان ضد التصنيف والعزل لأى فرد بسبب إعاقته، إلى جانب تزايد الاتجاهات المجتمعية نحو رفض الوصمة الاجتماعية للأشخاص ذوى الاحتباجات الخاصة. والدمج الاجتماعى هو علاقات المودة والعطف وحب الآخرين والتعاون واحترام حقوق الآخرين وتعلم العقائد والأفكار والتفاعل الاجتماعى مع الآخرين (أمبره بخش، و9 9 ( ) والدمج الاجتماعى لكبار السن هو دمج كبار السن فى الحياة الاجتماعية العادية والتعامل والمشاركة فى مرافق وأنثــطة المجتمع ســواء فى السـكن والاقامة مع تهيئة المجتمع لتقبلهم كأفراد منتجين ومنكاملين ومتفاعلين مع سائر أفراد المجتمع سواء فى محيط أسرهم أو فى المؤسسات المخصصة لرعايتهم. ) Lewis,

(B. Rene, 1987

ويقصد بالدمج الاجتماعى لكبار السن هنا هو إثترالك كبار السن فى الأنشطة والبرامج والمعسكرات

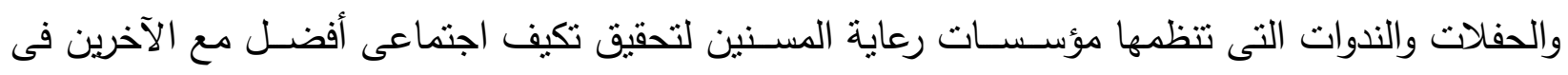
الأسرة، والمؤسسة، والمجتمع، وكذلك مشاركة أفراد الأسرة فى المناسبات الاجتماعية المختلفة. وتتحدد أهداف عملية الدمج الاجتماعى لكبار السن فيما يلى: ا- يســاعد الدمج الاجتماعى على تجنب المسـن الإنكفاء بمحاورته المسـتمرة وتدريبه على إنجاح تكيفاته السلوكية حتى يعاود المشاركة والانضمام إلى حياة الأسرة. ץ- عن طريق الدمج الاجتماعى يمكن مواجهة الاتجاهات السـلبية المعوقة لتقبل المسـنين فى بيئات ثقافية معينة وإدانة كافة أشكال الإساءة إليهم أو معاملتهم بطرق لا إنسانية. ب- دعم المنظمات غير الحكومية والهيئات الأهلية الأخرى فى مجالات رعاية كبار السـن من أجل تعزيز الدور المجتمعى فى وظيفة دمج كبار السن فى المجتمع. ع- تشــيع كبار السـن من الجنسـين فى أنشـطة الجمعيات الأهلية وإبداء الرأى حول القضـايا التى تمس أوضاعهم الخاصة أو شئون مجتمعهم المحلى لنأكيد عضويتهم الفاعلة. وللامج الاجتماعى لكبار السن العديد من المميزات منها على سبيل المثال: (خوله يحيى، ج . . ب) ا - يسـاعد الدمج الاجتماعى الاجتماعى لكبار السـن على تخليص أسـرهم من الثـعور بالذنب والاحباط خاصة كبار السن الذين بعيشون فى مؤسسات الرعاية الخاصة بهم. r- إناحة الفرص لكبار السن للانخراط فى الحياة العادية والتفاعل مع الآخرين. 
ب- التقليل من الفوارق الاجتماعية والنفسـية لكبار السـن وتخليص أسـرهم من الوصـمة التى يمكن أن يخلقها وجودهم فى مؤسسات الرعاية الخاصة بهم.

ع- يخلص الدمج الاجتماعى كبار السن من الأفكار الخاطئة حول أقرانهم داخل مؤسسات الرعاية. ه- تخليص كبار السـن من جميع أنواع المعيقات سـواء المادية أو المعنوية التى تحد من مشـاركتهم فى الى

$$
\text { جميع مناحى الحياة. }
$$

ج- يركز الدمج الاجتماعى على خدمة كبار السـن فى بيئاتهم والتخفيف من الصـعوبات التى يواجهونها سواء فى التكيف والتفاعل على مستوى أسرهم أو فى البيئة المحيطة. V- يسـاعد الدمج الاجتماعى كبار السـن على تعديل اتجاهات أفراد المجتمع وبالذات الثـباب والعاملين فى المؤسسـات المخصصـة لرعايتهم تجاه كبار السـن وذلك من خلال اكتشاف قدرات وخبرات كبار

$$
\begin{aligned}
& \text { السن. - الس } \\
& \text { وتتحدد انعكاسات الدمج الاجتماعى على كبار السن فيما بلى: } \\
& \text { - زيادة الدافعية لدى كبار السن. } \\
& \text { - ميادة الثقة بالنفس لدى كبار السن. } \\
& \text { - تطور التفاعل الاجتماعى لديهم. } \\
& \text { - - تكوين الاصدقاء الجدد كبديل لما فقدوه من صدقاء قدامى. } \\
& \text { - تحسن العلاقات الاجتماعية لكبار السن } \\
& \text { - - تحسن مستوى التعاون. } \\
& \text { - - ت تممل المسئولية. } \\
& \text { - انجاز المهام المنوط بها كبار السن. } \\
& \text { - - تعديل بعض السلوكيات الخاصة بكبار السن داخل دار الايواء. } \\
& \text { - - التسامح وتقبل الآخرين. - } \\
& \text { - زيادة الوعى الاجتماعى لدى كبار السن بما يدور حولهم. }
\end{aligned}
$$

The Elder Concept : مفهوم كبار السن

تشـــير كلمـة Elder فى اللغــة الانجليزيـة إلى المســن المتقدم فى العمر أو الكهـل (إلبـائ أنطون، § 9 ( ). وفى العلوم الاجتماعية يقصد بمرحلة الثـيخوخة هى السن التى ينتهى فيها نضـج الانسـان 
ويتحول النمو إلى عمليـة تفكلك وهبوط تدريجى فى قدرة أعضـــــاء الجســـم على القيام بوظـائفها (أحمد ذكى، (1919).

وتتعدد مفاهيم المسن طبقاً لتخصص العلم الذى يهنم بهذا المجال وسوف تعرض الباحثة هذا المفهوم كما يلى : يعرف المسن على أنه الثخص الذى تتضائل قوته وحيوبته مع ازدياد احتمالات تعرضه للاصابة بالأمراض، وخاصـة أمراض الثـيخوخة وازدياد شـعوره بالتعب والاجهاد عند الحركة الزائدة ونقص قدرته على الانتاج وبلوغه سن المعاش (نورهان فهمى،999 99 ( ). والمسـنين كفئة احصـائية هم السـكان الذين تبلغ أعمارهم ( • ج)سـتون عاماً أو تزيد، أما من الناحية الواقعية فإن هنالك ما يبلغون الثـيخوخة قبل سـن الستين، ومن تتأخر الثـيخوخة عندهم إلى ما بعد السـتين، وللفروق الفردية والظروف الاجتماعية دور كبير فى هذا (عزت حجازى،999 ( ). بينما يعرف المسـنين على أسـاس الجوانب الجسـمية من خلال اتجاه يحدد كبار السـن اعتماداً على ظهور بعض الأعراض مثل ذبول الجلد وتغير لون الثعر ، وتثاقل الحركات، وضعف السمع والبصر وظهور كثير من الأمراض (عادل جوهر، ب. . . ب). كما يعرف المسـنين بأنهم حالة من الاضــمحلال تعترى امكانات التوافق النفسـى والاجتماعى للفرد فتقل قدرته على استغلال امكاناته الجسمية والعقلية والنفسية فى مواجهة ضغوط الحياة . ومفهوم كبـار الســـن ينظر إليـه على أنـه مرحلـة عمريـة من مراحل النمو لهـا مظـاهر بيولوجيـة وسيكولوجية واجتماعية كما أنها الفترة التى يحدث خلالها ضعف وانهيار فى الجسم واضطراب فى الوظائف وبصــح الفرد أقل كفاءة وينســب اجتماعياً وسـئئ التوافق ومنخفض الدافعية بسـبـ ظروف الحياة (عبد

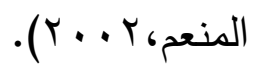

وكبار السـن فى هذه الدراسـة هم الأثـخاص الذين يقعوا فى المرحلة العمرية . آسـنـة فأكثر والذين يعيشـون فى محيط أسـرهم أو فى مؤسسـات متخصسصـة لرعايتهم ولديهم اضـطرابات اجتماعية فى علاقاتهم تعوق دمجهم اجتماعياً مع الأنساق الآخرى منل الأقران، الزملاء، والأسرة، والبيئة المحيطة. خامساً: البحوث والاراسات العلمية السابقة: يعكس التراث التقافى فى جميع التقافات مكانة كبار السن ومدى الاهتمام بهم ورعايتهم، لاسيما فيما يتعلق بعلاقاتهم بأفراد الأسرة، وبالآخرين فى المؤسسـات المخصصسة لرعايتهم، وبالبيئة المحيطة، وقد قامت الباحثة بالاطلاع على العديد من البحوث والدراسـات العربية والأجنبية السـابقة المرتبطة بإســتخدام نموذج 
الحياة فى العديد من المجالات، وكذلك الدراســات المرتبطة بدور الخدمة الاجتماعية فى مجال رعاية كبار السن منها على سبيل المثال: أولا: الدراسات السابقة والبحوث السابقة المرتبطة باستخدام نموذج الحياة فى العديد من المجالات: دراســة (سـامية عبد الرحمن همام) والتى اسـتهدفت اختبار فعالية نموذج الحياة فى خدمة الفرد فى علاج المشكلات الاجتماعية للمرأة المعيلة، وقد أظهرت النتائج قعالية النموذج فى علاج المشكلات المتعلقة بالقدرة على اتخاذ القرار ، المشكلات الصـحية، ومشكلات العلاقات الاجتماعية مع الأبناء، ومشكلات القدرة على تحقيق الذات، ومشـكلات التكيف مع البيئة الخارجية، والمشـكلات التعليمية، والمشـكلات الاقتصـادية

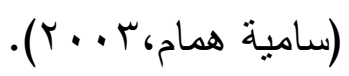

دراســـة (صــفاء عادل مدبولى) والتى اســتهدفت اختبار فعالية نموذج الحياة فى التخفيف من حدة مثــكلة الاغتراب الزواجى، وقد أظهرت النتائج فعالية النموذج فى التخفيف دن حدة المشـــــر السـلبية بين الزوجين وانعدام الاحســاس بالمســؤية المتبادلة والنظرة النتـــاؤمبة لمســتقبل الحياة الأســـرية (صــفاء

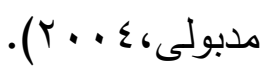

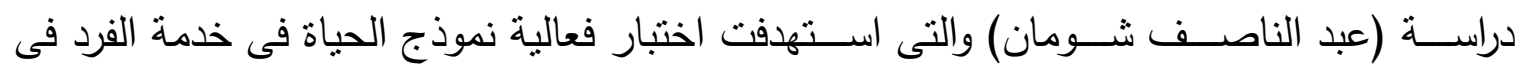
التخفيف من حدة الضـغوط الحياتية لدى المسـنين وقد أظهرت نتائج الدراسـة فعالية النموذج فى التخفيف من حدة الضغوط النفسية والاجتماعية والصحية والاقتصادية لدى المسنين (عبد الناصف شومان، ع . . ؟). دراسـة (هناء أحمد أمين) والتى اسـتهوفت اختبار العلاقة بين ممارسـة نموذج الحياة فى خدمة الفرد والتخفيف من حدة الخجل الاجتماعى لتلميذات المرحلة الاعدادية، وأظهرت نتائج الدراســـة أن نموذج الحياة أدى إلى تخفيف حدة مشكلة الخجل لتلميذات المرحلة الاعدادية (هنا أمين أحمد،ه . . ب). دراســـة (فاتن محمد عامر) والتى اســتهدفت اختبار ممارســـة نموذج الحياة فى تتمية المســـولية الاجتماعية لدى أطفال الثـوارع، وأثتتت نتائج الدراسـة أن ممارسـة نموذج الحياة أسـهم فى تتمية المسئولية

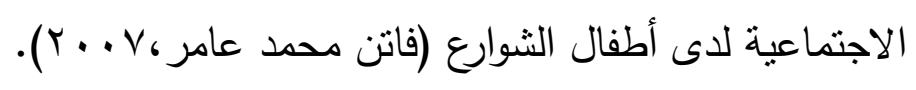
دراسـة (ابتسـام رفعت محمد) والتى اسـتهدفت اختبار نموذج الحياة فى خدمة الفرد وتحسـين نوعية الحياة لكبار السـن المسـاء إليهح وقد توصـلت الدراسـة إلى أن نموذج الحياة حقق فعالية فى تحسـين نوعية الحياة لكبار السن المساء إلبهح وذلك بالنسبة للحياة الاقتصادية، والحياة الصحية، والحياة الاجتماعية، والحياة النفسـية، كما أوضـحت النتائج أن نموذج الحياة فى خدمة الفرد مازال فى حاجة إلى التجريب فى مشـكلات

$$
\text { ومجالات آخرى (ابتسام رفعت محمد ادريس،ی، . . r). }
$$


دراسـة (نعيم شـلبى) والتى اسـتهدفت اختبار فعالية التدخل المهنى باسـتخدام نموذج الحياة فى خدمة الفرد للتخفيف من حدة الاضطرابات الاجتماعية والنفسية للمسنين داخل الدار، وقد توصلت نتائج الدراسة إلى فعالية هذا النموذج فى تخفيف حدة الاضطرابات الاجتماعية بين المسن وأسرته، وبين المسن وزملائه داخل الدار، والتخفيف من حدة الاضــرابات الاجتماعية المرتبطة بالأنشـطة الحياتية للمسـن داخل الدار ، وكذلك التخفيف من حدة الاضطرابات النفسية للمسنين داخل الدار (نعيم شلبى،م . . †). دراسة (نورة رشدى) والتى استهدفت فعالية التذخل المهنى بنموذج الحياة فى التخفيف من حدة سلوك العنف لدى الفتيات فى المؤسـسات الايوائية، وقد توصـلت نتائج هذه الدراسـة إلى أن نموذج الحياة فعال فى خفض حدة سلوك العنف لدى الفتيات المقيمات فى المؤسسات الايوائية (نورة رشدى عبد الواحد، I 1 ـ ץ). دراســة (محمد شــحاته) والتى اســتهدفت ممارســة نموذج الحياة فى خدمة الفرد لتخفيف الضــغوط الاسـربة المصـاحبة لحالات الاكتئاب، وقد توصـلت نتائج هذه الدراسـة إلى فعالية نموذج الحياة فى التخفيف من الضغوط الأسرية المصاحبة لحالات الاكتئاب (محمد شحاته مبروك، I 1 . ب).

ودراسـة (ديسـيير ورودنى، 2008) والتى أثـارت إلى أن نموذج الحياة يعمل على بلورة نماذج من شـأنها تسـاعد على زيادة القدرة على التمتع بالحياة The Leisure ability model ويعنى القدرة على خلق Rodney ) جو عام من البهجة والمرح الذى يؤثز ايجابيا على المزاج العام للشـص وخاصــة كبار السـن .(and Dieser, 2008 دراسـة (أوليفر شيللنج وآخرون،2006) والتى أوضـحت أن نموذج الحياة يسـاعد على تكيف الوضـع العضوى والنفسى والعقلى للمسن، والذى يؤتى بالحالة الصحية ونتمل تأثير وظائف الأعضاء وقصور أدائها Oliver K. Schilling and ) قصـــوراً ملموســـــاً كمـا تؤثز على ســـلوكه ونمط علاقاته بـالآخرين (Werner,2006

دراسة (دينيس رافائيل، 2009) والتى أوضحت أن نموذج الحياة يتضمن مكونات تحليلية ذات أبعاد متعددة يأخذ فى الاعتبار نوعية الحياة واسـلوب التعامل معها ومدى الاكتفاء والرضــا بها والتى ترتبط بنائياً ببعضـــها فضــلاً عن الأبعاد البيئية والتى أظهرتها الدراسـة، وهذا المكونات يمكن الاســفادة منها فى تحديد معالم نموذج الحياة المتغير فى أنماط سلوك المسن (Dennis Raphael,2009). دراسة (هربرت كوفى،2010) والتى أوضحت أن مرحلة الثيخوخة والتقدم فى السن تحتاج إلى رؤية ذات أبعاد تصـورية تعتمد على نموذج الحياة تسـاعدهم فى الانتقال التدريجى إلى مراحل السـن المتأخرة وما 
يصاحبها من زيادة عوامل الهرم من الصحة العامة وانحدار الآداء الوظيفى مع التقدم فى العدر ويتضح ذلك من هذه الدراسة التى اهتمت بتقديم وصفى لبعض ملامح حياة كبار السن (Herbert C. Covey,2010). دراسة (كارل جيرمين،2010) والتى أشتارت إلى أن نموذج الحياة يتضمن اضطلاع العميل بعمليات تفاعلية مع المواقف التى تحتاج إلى المســـاعدة نتيجة لظروف طارئة أدت إلى خلل فى منظومة الانســـان وعناصــر البيئة وتتطلب تذخل الاخصـــائى الاجتماعى لإعادة تحقيق التوازن، وهذا من خلال تقديم نموذج للحياة فى ممارسـة الخدمة الاجتماعية وجدير بالذكر أنه أظهر ما بسمى بشرط الحساة Live Course وهو Carel ) نموذج التطور الانسـانى المرتبط بظروف البيئة الطبيعية والاجتماعية والثقافية المحيطة بالانسـان

.(B. Germain,2010

دراسة (إلبكس جيترمان،2013) والتى أوضحت أن نموذج الحياة يعد من الأساليب التى تستخدم مع الأفراد المحيطين بعمق والذين تستخرقهم الصـراعات المستمرة ويكونون فى موقف ضـف فى الحياة وبعانون من الصـراع من أجل الحياة اقتصـاديا واجتماعياً أو معاناة الفقر والحاجة أو المعاناة من المثـــل الصــحية والوراثية والتى تحتاج إلى تحديد اسلوب للحياة ينتشلها من مثاكلها بمساعدة الاخصائى الاجتماعى، ويتضح

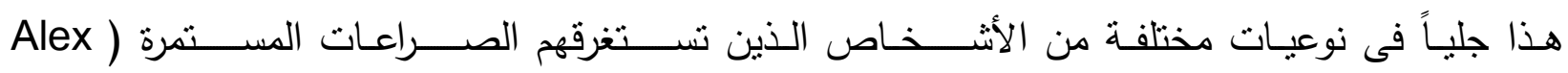
.(Gillerman,2013

دراسة (أليس ميللر، 2015) والتى أشارت إلى أن تتبئ اسلوب معين فى نهج الحياة يعتمد على طرق مختلفة فى التعامل ويراعى ردود الأفعال والنظر إلى الأمور والاعتبارات السـيكولوجية، ويسـاعد على وضـع ضوابط وقواعد محددة فى صورة اسلوب الحياة وبحل محل الأساليب المعتادة ومن ثم يعمل على تعديل مسار حياة الأفراد وعلاقاتهم بالمجتمع، وهذا من خلال نموذج الحياة (Alice Call Miller,2015). ثانياً: الدراسـات والبحوث السـابقة المرثبطة بدور الخدمة الاجتماعية فى مجال رعاية كبار السـن منها على سبيل المثنال:

دراسـة (اقبال السـمالوطى) والتى اسـتهدفت مواجهة مشــاكل المسـنين عن طريق اسـتشمار طاقات المسـنين بالمشـاركة الاجتماعية أو بالمشـاركة فى الانتاج بمقابل مادى والتوصـل إلى بعض الاتجاهات التى سـتهم فى تظوير أهداف واسـوب عمل المؤسسـات فى مجال المسنين، وأظهرت نتائج الدراسـة أن مشكلات المسـنين تثمثل فى الحالة إلى الثــور بالمكانة الاجتماعية وشـخل أوقات الفراغ وتقوية العلاقات الاجتماعية (اقبال الامير السمالوطى، • 99 ( ) ). 
دراســة (ثريا جبريل) والتى اسـتهدفت التعرف على المشـكلات التى تصــاحب كبار السـن، وأثنتت نتائجها أن المشكلات التى تصاحب كبر السن تتمنل فى انقطاع الصلة بالأهل والأقارب والإحساس بالإهمال والانعزال وعدم القدرة على استثمار وقت الفراغ (ثريا جبريل، ب 9 ( ). وأثنارت دراسة (فيكتور باكون، 1992) والتى استهدفت التخفيف من الضغوط الحياتية التى يتعرض لها المسن، وأثتتت نتائج الدراسة إلى أن مستوى المشكلات والضغوط التى يتعرض لها المسن تتخفض حينما يزداد الاهتمام بالناحية الاقتصـــادية، وممارســـة أنشــــة الحياة اليومية والتدعيم المجتمعى وتقدير المكانة الاجتماعية لهم (Victoria Bacon,1992). دراسـة (رفعت عبد الباسـط) والتى اسـتهدفت التعرف على مشـكلات واحتياجات المسـنين، وكان من نتائجها أن المسنين تواجهرم مشكلات متعددة تتمنل فى مشكلات نفسية، واجتماعية، واقتصادية، ومشكلات وقت الفراغ والإهمال (رفعت عبد الباسط محمد، 999 ( ). ودراسـة (حنان جمعه) والتى استهدفت المقارنة بين المشكلات الاجتماعية والنفسية للمسنين فى دور الرعاية الايوائية والمترددين على نوادى المسـنين، وأن أهم المشـكلات التى بعانى منها المسـنين هى ضـعف العلاقات والشعور بالاكتئاب وعدم الاحساي بالأمن والطمأنينة (حنان حسن جمعه، ؛ 9 ( ). دراسـة (على الطراح) والتى اسـتهذفت التعرف على المشـكلات التى تواجه كبار السـن مع أسـرهم، وأوضـحت نتائجها أن المسـن الذى يقيم مع أسـرته يثـعر بالنبذ والاهمال والتهميش الاجتماعى (على أحمد

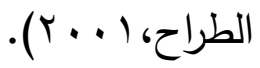

دراسـة (جمال شـكرى) والتى اسـتهدفت اختبار فعالية برنامج التذخل المهنى من منظور خدمة الفرد الجماعية فى تخفيف مشــكلة العزلة الاجتماعية للمسـنين، وأثنتت نتائج الدراســة فاعلية برنامج التـخل من منظور خدمة الفرد الجماعية فى التخفيف من مشكلة العزلة للمسنين (جمال شكرى محمد عثمان، ب . . ( ). دراسـة (ستتفن) والتى استتهدفت تحديد دور المؤسسـات النفسية فى الحد من الإسـاءة الموجهة لكبار السـن أوضـحت نتائجها أن أكثر من 7 (\% من المسـنين المترددين على هذه المؤسســات يتعرضـون داخلها للإيذاء والتجاهل والاهمال الثديد من أجل الحصول على الخدمات النفسية (Stephen,2002). دراسـة (برجيرون) والتى أوضـت نتائجها أن قضية الإسـاءة لكبار السن تلقى اهتماماً تشـريعياً كبيراً ضد أى شكل من أشكال الاساءة الموجهة إلبهم كالإيذاء الجسدى والنفسى وذلك من جراء إهمالهم أو تجاهلهم كما تشير الدراسة إلى أن المساء إليهم من كبار السن يتعرضون للاستغلال المادى (Bergerno,2003) 
دراسـة (هيام محمد على) والتى اسـتهدفت التوصـل إلى تصـور مقترح لدور اخصـائى خدمة الجماعة باسـتخدام نموذج الأزمة فى مواجهة مشـكلة اسـاءة كبار السـن بأثـكالها، وكان من نتائج الدراسـة أن أثـكال الاسـاءة لكبار السـن تتمنل فى الاسـتخلال المادى والايذاء النفسىى والايذاء البدنى، وعدم تلبية الاحتياجات، والرفض والنبذ، والاهمال، وتوصــلت الدراســة إلى تصــور مقترح من خلال نموذج الأزمة لدور اخصــائى الـى الجماعة للعمل مع مشكلة اساءة كبار السن (هيام محمد على، ج . . ب) دراســة (رثــاد عبد اللطيف) والتى أظهرت أن مدخل التأهيل المرتكز على المجتمع أحد المرتكزات الأسـاسـية التى توضــح التكافل ما بين فئات المجتمع ومن هم فى حاجة إلى دعم ومســاعدة من المسـنين وغيرهم من الفئات وهذا المدخل يعتمد على الجها المشـترك ما بين المسنين أنفسهم وأسـرهم والبيئة المحيطة بهم بمـا يحقق لهم توافق اجتمـاعى أفضـــلـ وذلك لاســـتثـار كافة الطاقات المتوفرة لدى المســـنين لتلبية احتياجاتهم وفى نفس الوقت المســاهمة فى تتمية المجتمع وبالتالى تتحول من طاقة خاملة إلى طاقة محركة وكيان قادر على خدمة المجتمع (رشاد عبد اللطيف، و . . ؟). ومن خلال العرض السـابث للاراسات السابقة التى ارتبطت بموضوع دراسة الباحثة يمكن الخروج بمجموعة من المؤثرات التالية: أوضـحت الدراسـات السـابقة فعالية نموذج الحياة فى العديد من المجالات المتتوعة مع العديد من المشـكلات المختلفة التى يعيشـها الانسـان مثل المشـكلات الاجتماعية للمرأة المعيلة، والتخفيف من مشـكلات الاغتراب الزواجى، والتخفيف من حدة الضغوط الحياتية لاى المسنين، والتخفيف من حدة الضغوط الأسرية المصاحبة لحالات الاكتئاب، والتخفيف من حدة سـلوك العنف لاى الفتيات فى مؤسـســات الايواء، والتخفيف من حدة الخجل الاجتماعى لتلميذات المرحلة الاعدادية، وتتمية المسئولية الاجتماعية لدى أطفال الثــوارع، وتحسـين نوعية الحياة لكبار السن المساء إليهم. أن نموذج الحياة يستخدم فى الظروف الضاغطة كأحد الأساليب أو النماذج الثخصية للحياة المرتبطة بحالة الثــــص من حيث النظرة إلى ما حوله ودرجة إقباله على العيش مع الآخرين، والتخفيف من الكآبة واليأس الناجمين عن طبيعة الضــوط المسـتمرة على الثـخص أو الاسـتعداتد للاسـتجابة للمثيرات الخارجية وعدم القناعة بما لديه من امكانات وقدرات، وإصـــدار الاحكام حول نوعية نموذج الحياة يجب أن يتم فى صــورة تكاملية تتضمن فهم الاختلافات وأوجه التشابه بأنماط السلوك مع الوضع فى الاعتبار اسلوب الحياة التاريخى الذى يراعى التطور والنمو فى الثخصية من أجل تحديد معالم نموذج الحياة المنطور • 
ترى الباحثة أن نموذج الحياة فى طريقة العمل مع الأفراد فى محيط الخدمة الاجتماعية يكون له دوراً فعالاً فى تعزيز الدمج الاجتماعى لكبار السن. تُودئ. لا توجد دراسـات وبحوث سـابقة فى حدود علم الباحثة اسـتخدمت نموذج الحياة فى تعزيز الدمج الاجتماعى لئى

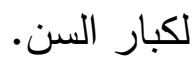

أوضــت الدراسـات السـابقة أن مهنة الخدمة الاجتماعية لها دوراً بارزاً فى مجال رعاية كبار السـن وخاصـة

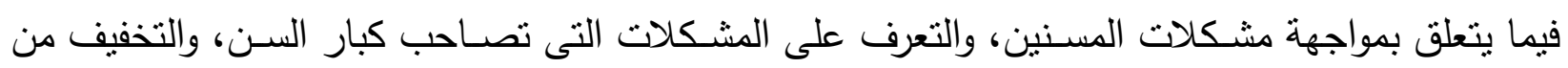
حدة الضغوط الحياتية التى يتعرض لها المسنين. الإطار المنهجي للاراسة: أولاً: نوع الدراسة وإلمنهج المستخدم: تتنمى هذه الدراســــة إلى نمط الدراســـــات شـــــــهـ التجريبيـة التى تعتمد على المنهج التجريبي Experimental Method تابع وهو تعزيز الدمج الاجتماعى لكبار السن المقيمين بدور الايواء.

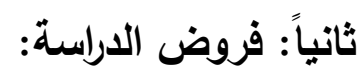
تحاول الدراسة اختبار الفرض الرئيسى التالى: توجد علاقة ايجابية دالة احصائياً بين استخدام نموذج الحياة فى خدمة الفرد وتعزيز الدمج الاجتماعى لئى لكبار السن. ويتفرع من هذا الفرض الرئيسى الفروض الفرعية الثناثة الآتية:

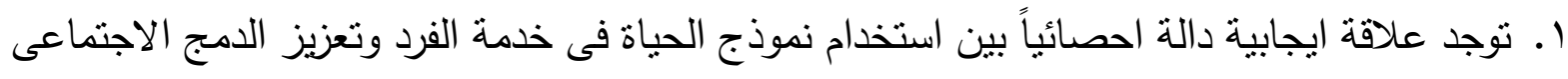
لكبار السن فى محيط الأسرة. r. توجد علاقة ايجابية دالة احصائياً بين استخدام نموذج الحياة فى خدمة الفرد وتعزيز الدمج الاجتماعى لكبار السن فى مؤسسة الايواء. r. توجد علاقة ايجابية دالة احصائياً بين استخدام نموذج الحياة فى خدمة الفرد وتعزيز الدمج الاجتماعى لكئ لكبار السن فى المجتمع. ثالثا: أدوات الدراسة: تحددت أدوات الدراســـة الحالية فى أداة رئيســية هى مقياس الدمج الاجتماعى لكبار الســن من (إعداد الباحثة) وقد اتبعت الباحثة الخطوات التالية فى إعداد هذا المقياس: 
- - الاطلاع على العديد من الدراسات والبحوث العلمية السابقة ذات الصلة بموضوع الدراسة الحالية. - - القيام بعمل أكثر من زيارة مبدانية للمجال المكانى للاراسـة (مؤسـسـة دار الحنان والتكريم لرعاية وايواء المسنين بمحافظة بورسعيد). - - الاطلاع على بعض المقاييس العلمية ذات الصـلة بموضـوع الدراسـة الحالية بهدف التعرف على الابعاد والمؤشرات التى يمكن الاعتماد عليها فى بناء هذا المقياس. - - حددت الباحثة موضــوع المقياس الرئيسـى فى تعزيز الدمج الاجتماعى لكبار الســن، وحددت الأبعاد الفرعية فى: o البعد الأول: الدمج الاجتماعى لكبار السن فى محيط الأسرة. o البعد الثانى: الدمج الاجتماعى لكبار السن فى مؤسسة الايواء. o البعد الثالث: الدمج الاجتماعى لكبار السن فى المجتمع. - قامت الباحثة بصياغة أبعاد وعبارات المقياس بشكلها المبدئى واستخدمت التذرج الثلاثى أمام كل عبارة بوضـــع ثناث اسـتجابات لكل عبارة، الأولى (دائماً) وتعطى (ب)درجات، والثانية (أحياناً) وتعطى درجتان، والثالثة (نادراً) وتعطى درجة واحدة وذلك للعبارات الايجابية أما العبارات السلبية فتعطى درجات كالتالى: (دائماً) درجة واحدة، و (أحياناً) تعطى درجتان، و (نادراً) تعطى ثثلاث درجات.

- فى ضــوء نتائج التحكيم بلغ عدد عبارات المقياس (0 ـ)عبارة مقسـمة على ثلاثث أبعاد كل بعد

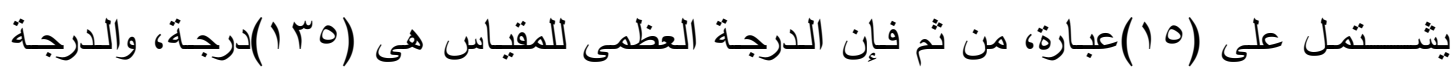
المتوسطة هى ( • 9)درجة، والدرجة الصغرى هى (0 ( ع)درجة.

صدق المقياس: أ- صدق المحكمين:

قامت الباحثة بعرض المقياس فى صورته المبئية على مجموعة من أعضاء هيئة التدريس المتخصصين فى مجال الخدمة التعليمية، لتحديد مدى مناسبة العبارات لكل بعد حيث يتكون المقياس من ثناثة أبعاد: البعد الأول : الدمج الاجتماعى لكبار السـن فى محيط الأســرة، البعد الثانى: الدمج الاجتماعى لكبار الســن فى مؤسـســة الإيواء ، البعد الثالث: الدمج الاجتماعى لكبار السـن فى المجتمع، وتم إجراء التعديلات المقترحة للسادة المحكمين من حذف وتعديل وإضافة وإعادة صباغة بعض العبارات وتراوحت نسب الاتفاق بين السادة 


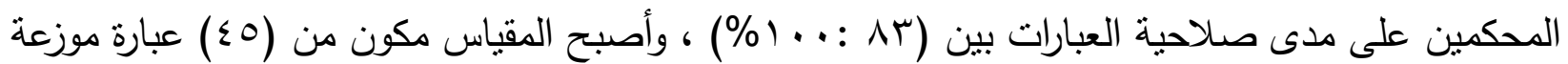
على أبعاده الثلاثة.

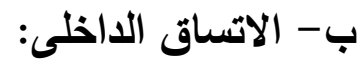
يعد صـدق المحكمين من أنواع الصـدق السـطحى أوالظاهرى؛ لذلك قامت الباحثة بتطبيق المقياس على عينة اسـطلاعية من كبار السـن بلغ عددها (ن = 0 (1) وذلك لحسـاب الاتسـاق الداخلى عن طريق حسـاب معاملات الارتباط بين درجة كل عبارة والدرجة الكلية للبعد الفرعى بواســــة الحزمة الإحصـــائية للعلوم الاجتماعية والمعروفة اختصاراً بSpss.V.22 فكانت قيم معاملات الارتباط كما هو موضت بجدول ( () :

\section{جدول (1)}

قيم معاملات ارتباط عبارات المقياس بالدرجة الكلية للبعد الفرعى

\begin{tabular}{|c|c|c|c|c|c|c|c|}
\hline قيمة معامل & رقم & قيمة معامل & رقم & قيمة معامل & رقم & قبمة معامل & رقم \\
\hline$* *,, \vee \neg \wedge$ & $r v$ & $* *,, V Y r$ & ro & $*, \mu, \Lambda$ & Ir & $* *, \vee \vee \backslash q$ & 1 \\
\hline$* *,, \vee Y \diamond$ & rᄉ & $* *, \vee \vee 1$ & rq & $* *, \vee \vee \neg 0$ & $1 \varepsilon$ & $* *, \vee \wedge \wedge$ & $r$ \\
\hline$* *, \vee \vee \neg ~$ & rq & q س & $r V$ & **, , & 10 & $* *, \vee \vee 10$ & $r$ \\
\hline$* *,, V \leq r$ & $\varepsilon$. & $* *,, \vee 14$ & $r \wedge$ & $*, \mu \wedge \neg$ & 17 & $* *,, \vee Y \bullet$ & $\varepsilon$ \\
\hline$* *,, \vee \neg \vee$ & $\leqslant 1$ & $*, r$, & rq & $* *,, \vee \neg \diamond$ & $1 \mathrm{~V}$ & $* *,, \vee Y \diamond$ & 0 \\
\hline$* *,, \vee \wedge \bullet$ & $\varepsilon r$ & $* *,, \vee 01$ & r. & $* *, V_{Y}$ & 11 & $* *,, \vee \wedge \neg$ & 7 \\
\hline$* *,, \vee \vee \varepsilon$ & $\varepsilon$ & $* *, \vee \vee \wedge$ & r & $* *,, \vee r \varepsilon$ & 19 & $*, \mu, r$ & V \\
\hline$* *,, V Y V$ & $\varepsilon \varepsilon$ & $* *, \vee \vee \diamond \diamond$ & $r r$ & $* *,, \vee \wedge \vee$ & $r$. & $* *, \vee \vee \neg \vee$ & $\Lambda$ \\
\hline 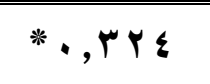 & $\varepsilon 0$ & $* *,, V Y r$ & r & $* *, \vee \vee \neg 0$ & YI & **, , VYO & 9 \\
\hline- & - & $*, \mu, v$ & r & $* *,, \vee q 9$ & $r r$ & **, , V r & 1. \\
\hline- & - & $* *, V \leq \mu$ & ro & $* *,, V M r$ & $r r$ & $* *, V_{Y}$ & 11 \\
\hline- & - & $* *, \vee \vee \neg 0$ & q & $* *,, \vee \vee$ & $r \varepsilon$ & $* *, V Y_{1}$ & Ir \\
\hline
\end{tabular}


يتضح من الجدول السابق أن قيم معاملات ارتباط العبارات بالدرجة الكلية للبعد الفرعى دالة إحصائياً عند مستوى ا •, • والبعض الآخر دال إحصائياً عند مستوى 0 ., • أى أنه بوجد اتساق ما بين عبارات المقياس والأبعاد الفرعية ؛ مما يثير إلى أن المقياس على درجة مناسبة من الاتساق.

ثبات المقياس: أ- طريقة معامل ألفا لكرونباخ: Coefficient Cronbach's Alpha اسـتخدمت الباحثة لحسـاب ثبات المقياس معامل ألفا لكرونباخ فى حالة حذف درجة العبارة من الدرجة الكلية للمقياس فبلغت قيمة معامل ألفا العام للمقياس ككل (VAV, • ) كما تم حساب معامل ثبات كل عبارة فكانت قيم معاملات ثبات العبارات كما هو موضح بجدول (r) جدول (r)

قيم معاملات ألفا لعبارات المقياس

\begin{tabular}{|c|c|c|c|c|c|c|c|}
\hline قيمة معامل & رقم & قيمة معامل & رقم & قيمة معامل & رقم & قيمة معامل & رقم \\
\hline$\cdot, V \vee \varepsilon$ & $r v$ & $\cdot, \vee \vee V$ & ro & $\cdot, \vee \circ \bullet$ & Ir & $\cdot, \vee 19$ & 1 \\
\hline$\cdot, V \leq 1$ & $\mu \wedge$ & $\cdot, V \odot V$ & rq & $\cdot, \vee \wedge \bullet$ & $1 \varepsilon$ & • , & $r$ \\
\hline$\cdot, V \leq 1$ & rq & $\cdot, \mathrm{V} \vee \mathrm{I}$ & rV & - ,VYV & 10 & •, , & $r$ \\
\hline$\cdot, \vee \vee q$ & $\varepsilon$. & $\cdot, V \otimes V$ & $r \wedge$ & - , VAr & 17 & - , VYO & $\varepsilon$ \\
\hline מצ & $\leqslant 1$ & - , VVr & rq & $\cdot, \vee \wedge 1$ & IV & $\cdot, \vee \vee \wedge$ & 0 \\
\hline$\cdot, V \bullet V$ & $\varepsilon r$ & •, VrV & r. &., 871 & 11 & $\cdot, V \circ r$ & 7 \\
\hline - , Vrr & $\varepsilon r$ & $\cdot, \vee \wedge \varepsilon$ & ו &,,$\vee \vee \varepsilon$ & 19 & •, Vrr & $v$ \\
\hline$\cdot, \vee \circ \neg$ & $\varepsilon \varepsilon$ & $\cdot, \vee \wedge r$ & rr &,,$\vee 1$. & $r$. & •, VYr & $\Lambda$ \\
\hline •, & $\varepsilon 0$ & $\cdot, \vee \wedge 1$ & r & $\cdot, V \cdot 0$ & Y & •, , & 9 \\
\hline- & - & $\cdot, \vee \vee V$ & $r \varepsilon$ & , , VI. & $r r$ &,,$V Y \varepsilon$ & 1. \\
\hline- & - & $\cdot, \vee \vee \wedge$ & ro & $\cdot, \vee \wedge 1$ & $r r$ & $\bullet, \vee \wedge \mu$ & 11 \\
\hline- & - & $\cdot, \vee 71$ & q & $\cdot, V \leq r$ & $r \varepsilon$ & - , VVr & Ir \\
\hline
\end{tabular}


يتضـح من الجدول السـابق أن جميع قيم معاملات ثبات العبارات أقل من معامل ثبات المقياس ككل مما يثير إلى أن العبارات على درجة مناسبة من التبات. ب - مريقة التجزئة النصفية:

للتحقق من ثبات المقياس ككل تم اســـتخدام طريقة التجزئة النصــفية Split half وبلغت قيمة معامل الارتباط بين نصـفى المقياس (OV0, • • ) وبعد تصــيح أثز التجزئة بمعادلة جيتمان Guttman بلغت قيمة فئه

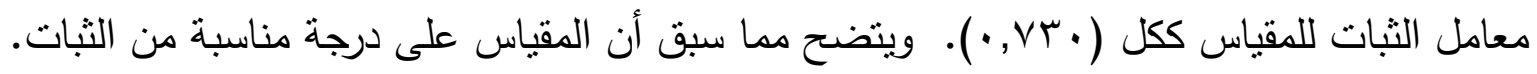

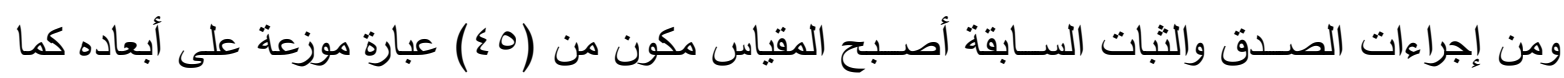

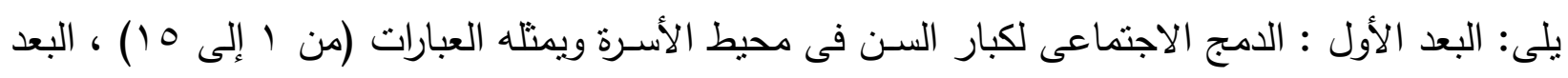

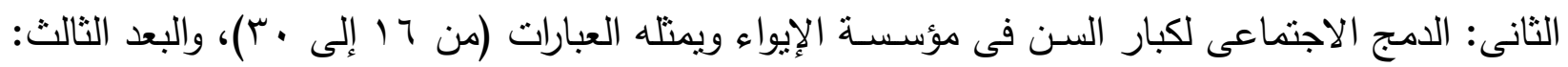

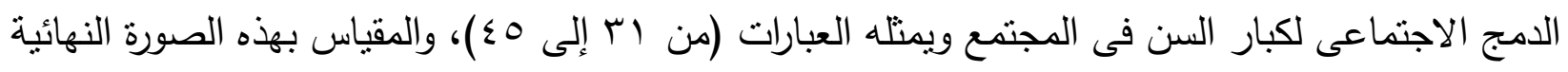
صالح للتطبيق على عينة الدراسة الأساسية.

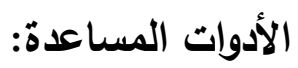

وهى مجموعة الأدوات التى استخدمنها الباحثة للتعرف على مجتمع الدراسة ومنها:

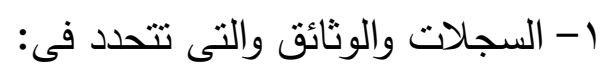

- - احصـاءات الدار حيث قامت الباحثة بالاطلاع على الاحصـاءات الدورية الموجودة بالدار وتبين

$$
\text { عدد كبار السن المقيمين بها. }
$$

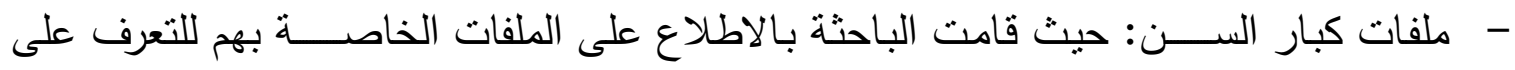
إجراءات الدار فى اسـتقبال كبار السـن ومعرفة أهم المسـتندات التى يحتوى عليها ملفات كبار

$$
\text { السن. }
$$

$$
\text { r- البيانات المعرفة بكبار السن: }
$$

من خلال مجموعة من الأسئلة تضمنتها أداة القياس للحصـول على البيانات الأولية الهامة عن حالات

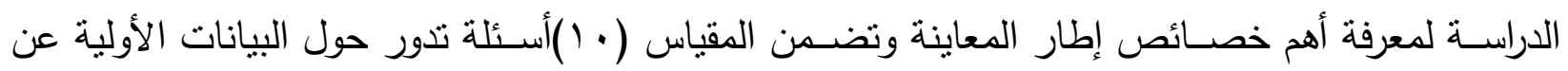

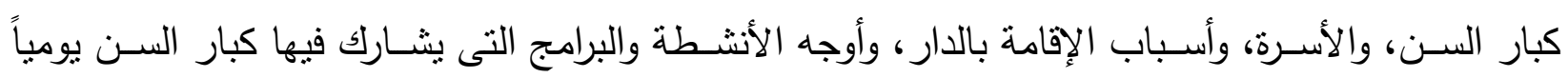


قامت الباحثة بتطبيق نموذج الحياة فى خدمة الفرد على كبار الســن المقيمين بدار الحنان والتكريم لايواء ورعاية المسنين بمحافظة بورسعيد.

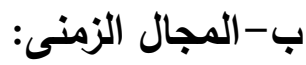
اسـتغرقت الدراسـة فترة زمنية تقدر بسـتة أشــهر ابتداء من منتصـف أغسطس 9 أ ـ حتى منتصـف شـهر

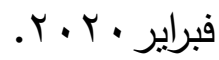
ج-المجال البشرى: قامت الباحثة بحصـر عدد كبار السـن المقيمين بدار الحنان والتكريم وتبين أن عددهم (9ه)مفردة وبتطبيق شروط اختيار العينة عليهم تبين أن من تتطبق عليهم شروط العينة هم (Y0)مفردة، ثم قامت الباحثة بتطبيق مقياس تعزيز الدمج الاجتماعى لكبار السـن عليهم وتم اختيار (0 ( )مفردة عشـوائياً ممن حصـلوا على أعلى الدرجات على المقياس، وتتوافر فيهم شروط العينة كالتالى: 1- أن يتجاوز المسن عمر ستون عاماً. r- أن يكون من المقيمين بدور الايواء إقامة تامة. r- أن يكون المسن لديه أسرة وأبناء خارج الدار . ع - أن يكون حاصلاً على أعلى درجات على مقياس الدمج الاجتماعى. ه- أن يكون المســن لديه الاســـتعداد الكامل للتعاون مع الباحثة خلال فترة تتفيذ برنامج التخخل المهنى. وصف عينة الاراسة:

جدول (r)

العدد والنسب المئوية للنوع

\begin{tabular}{|c|c|c|}
\hline النسبة \% & العدد & النوع \\
\hline$\% r^{\prime}, V$ & $\varepsilon$ & ذكر \\
\hline$\% \vee r, r$ & 11 & أنثى \\
\hline$\% 1 \ldots$ & 10 & المجموع \\
\hline
\end{tabular}

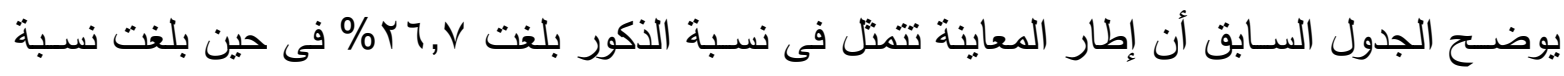

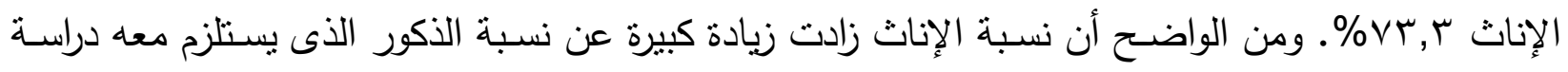


التغيرات التى حدثت فى المجتمع وتدفع إلى نواجد المسـنات بثـكل أكبر من المسـنين فى دور الايواء عكس الماضى كان نسبة الذكور هى الأكبر فى دور المسنين.

جدول (\&)

العدد والنسب المئوية للسن

\begin{tabular}{|c|c|c|}
\hline النسبة \% & 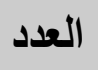 & السن \\
\hline$\%$ & - & أقّل من · 7 سنة \\
\hline \% & $r$ & . 1 سنة \\
\hline \% & 0 & 07 سنة \\
\hline$\% \circ \mu, \varepsilon$ & $\Lambda$ & أكثر من ه 7 سنة \\
\hline$\% 1 \ldots$ & 10 & المجموع \\
\hline
\end{tabular}

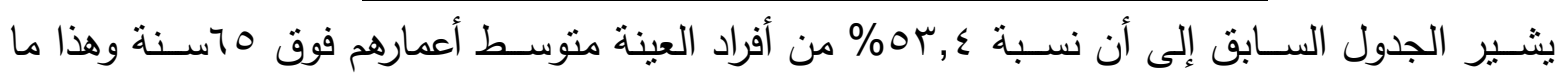

يتطلب ضرورة وضع برنامج اجتماعى يساهم فى تعزيز العلاقات والدمج الاجتماعى لكبار السن داخل وخارج دار الايواء.

\section{(0) جدول (1)}

العدد والنسب المئوية لتاريخ الالتحاق بالدار

\begin{tabular}{|c|c|c|}
\hline النسبة \% & العدد & الالتحاق بالدار \\
\hline$\%$. & - & منذ سنة \\
\hline$\%$. & - & منذ سنتين \\
\hline$\%$ & • & منذ ثلاث سنوات \\
\hline$\% r \mu, r$ & $\bullet$ & منذ أربعة سنوات \\
\hline$\% 77, V$ & 1. & منذ أكثر من أربعة سنوات \\
\hline$\% 1 \ldots$ & 10 & المجموع \\
\hline
\end{tabular}


يتضح من الجدول السـابق أن نسبة مائة بالمائة التحقوا بالدار منذ أربعة سنوات فأكثر، وذلك يثير إلى ضـرورة وجود شبكة علاقات واتصـالات بين المسنين وبعضـهم بالدار وعلى الرغم ن ذلك فهنالك صسوبة فى الدمج الاجتماعى بينهم كما أوضـح المقياس، الأمر الذى بتطلب ضـرورة تصـيم برامج وأنشطة لكبار السن تساعدهم على تعزيز دمجهم اجتماعياً مع أقرانهم بالدار، وأسرتهم، والمجتمع بأكمله.

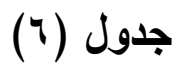

العدد والنسب المئوية للحالة التعليمية

\begin{tabular}{|c|c|c|}
\hline النسبة \% & العدد الع & الحالة التعليمية \\
\hline \% rr,r & 0 & أمى \\
\hline$\%$ ४. & 9 & يقرأ ويكتب \\
\hline$\%$. & - & إبتدائية \\
\hline$\%$. & - & إعدادية \\
\hline$\% \square, \vee$ & 1 & مؤهل متوسط \\
\hline$\% 1 \ldots$ & 10 & المجموع \\
\hline
\end{tabular}

يشير الجدول السابق إلى أن إطار المعاينة بالنسبة للحالة التعليمية أن نسبة المسنين الأمبين س,سب\%

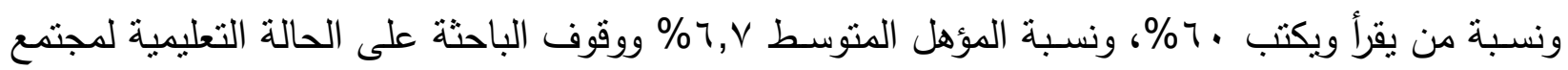
الدراسـة ساعدها على تحديد أساسيات فى البرنامج المهنى وتحديد أساليب وتكنيكات علاجية مناسبة لطبيعة مجتمع الدراسة وحالتهم التعليمية.

جدول (v)

العدد والنسب المئوية لحالة الصحية

\begin{tabular}{|c|c|c|}
\hline النسبة \% & العدد & الحالة الصحية \\
\hline \% & 0 & جيدة \\
\hline \%ч , レ & v & متوسطة \\
\hline$\%$. & . & سيئة \\
\hline$\% 1 \ldots$ & 10 & المجموع \\
\hline
\end{tabular}


يبين الجدول السـابق الحالة الصـية لأفراد عينة الدراسـة حيث تبين أن نسبة س,بس\% حالتهم الصـحية جيدة، فى حين أن نسـبة 7, > 7\% حالتهم الصـحية متوسـطة، وذلك بسـاعد على معرفة اللتوقعات بالنسـبة لاستمرار أفراد العينة فى المشاركة فى برنامج التذخل المهنى.

جدول (^)

العدد والنسب المئوية للعمل السابق قبل الالتحاق بالدار

\begin{tabular}{|c|c|c|}
\hline النسبة \% & العدد & العمل السابق \\
\hline$\%$ & - & موظف \\
\hline$\%$ & . & أعمال حرة \\
\hline$\% 77, V$ & 1. & بالمعاش \\
\hline \% r & - & بدون عمل \\
\hline$\% 1 \ldots$ & 10 & المجموع \\
\hline
\end{tabular}

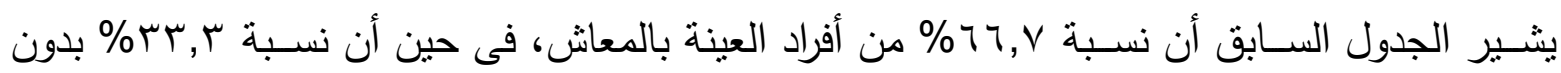
عمل، وهذا بعكس أن وجود هؤلاء بالدار فى حالة تأقلم تام أفضــلـل من مما كانوا يعملون بوظائف أو أعمال حرة، وقد يساعدهم الدمج اجتماعياً فى زيادة التأقلم والتعايش مع الآخرين فى نفس الدار. جدول (9)

العدد والنسب المئوية للاخل الشهرى

\begin{tabular}{|c|c|c|}
\hline النسبة \% & 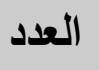 & الاخل الشهرى \\
\hline$\% \varepsilon$ & 7 & أقل من . . . جنيه \\
\hline$\% \leq 7, V$ & V & أقل من . . . جنيه \\
\hline$\%$ I & r & أقل من ... . ج جنيه \\
\hline$\%$. & - & أقل من . . . جنيه \\
\hline$\%$. & - & أكثر من . . ع جنيه \\
\hline$\% 1 \ldots$ & 10 & المجموع \\
\hline
\end{tabular}




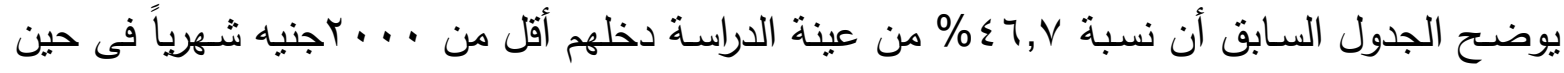

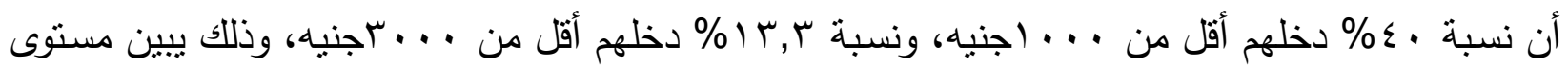
الدخل المنخفض لديهم فى ضـوء ارتفاع الاسـعار وخاصــة الأدوية ومقابل إقامتهم بالدار حيث أن غالبيتهم كانوا بالمعاش ولا برتبطون بعمل معين قبل دخولهم الدار .

\section{جدول (· (1)}

العدد والنسب المئوية لأسباب الإقامة بالدار

\begin{tabular}{|c|c|c|}
\hline النسبة \% & العدد العد & أسباب الإقامة \\
\hline$\%$ Ir, & r & أسباب صحية \\
\hline$\% \leq \neg, V$ & $\mathrm{v}$ & أسباب نفسية \\
\hline \% rr,r & 0 & أسباب أسرية \\
\hline$\% \leq$ & 9 & أسباب اجتماعية \\
\hline$\% \wedge$. & ir & أسباب خاصة بالسكن \\
\hline
\end{tabular}

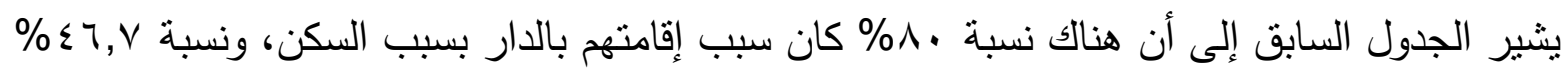

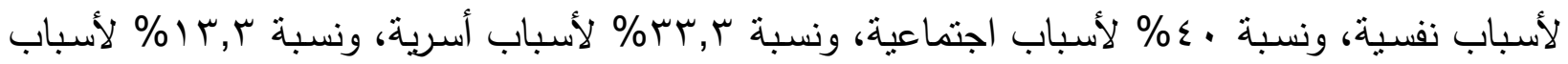
صحية. وهذا يبين أن هناك أسباب متتوعة لإقامة المسن بدور الايواء، مما بيتلزم معه ضرورة تدعيم وتعزيز

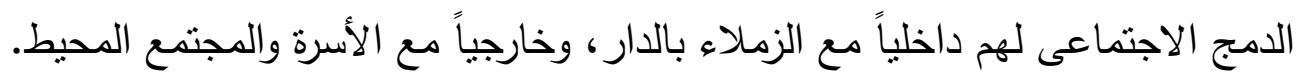
خامساً: برنامج التدخل المهنى فى ضوء معطيات نموذج الحياة فى خدمة الفرد:

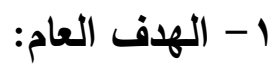

يتحدد الهدف العام للبرنامج فى الهدف الرئيسى للاراسة وذللك على النحو التالى: اختبار فاعلية نموذج الحياة فى خدمة الفرد لتعزيز الدمج الاجتماعى لكبار السن المقيمين بدار الايواء. وينبثق من هذا الهدف ثلاثة أهداف فرعية على النحو التالى:

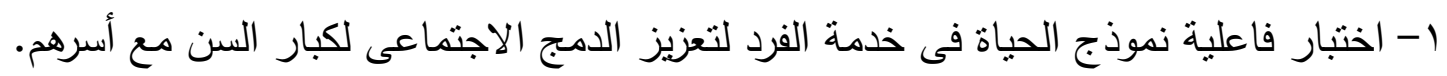

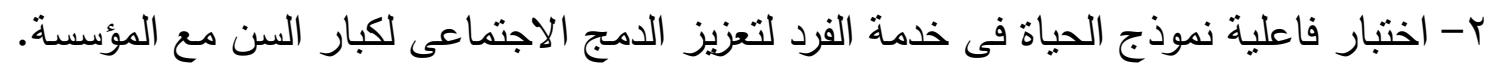

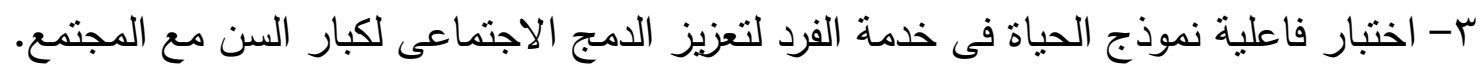
وتتحقق هذه الأهداف من خلال الآتى: 
- تحرير الطاقات الداخلية لكبار السن وإعطاءهم القوة للعمل والاستمرار فى الحياة.

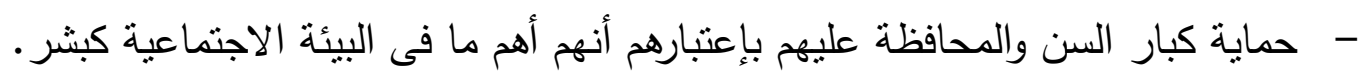

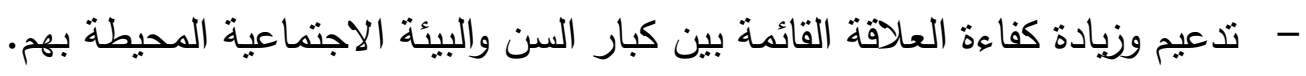
- - تدعيم قوة شـصـية كبار السـن وتحسين شبكة علاقاتهم الاجتماعية بالانسـاق البيئية الرسمية لهية وغير الرسمية من خلال تعزيز دمجهم اجتماعياً. r - مبررات استخدام نموذج الحياة مع كبار السن:

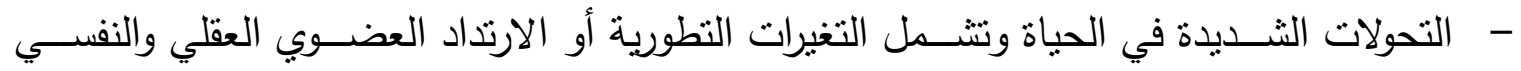

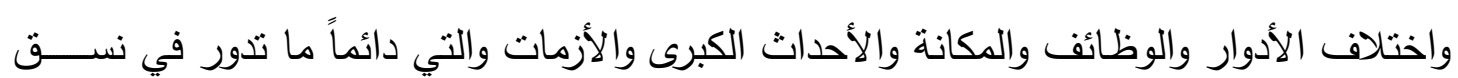
بيئي مباشر بعلاقات كبار السن وتتعكس عليه. - عدم التوافق في العديد من التفاعلات المتبادلة بين المســـن والبيئات الاجتماعية أو الماديـة

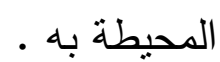
- الصـعوبات الملموسـة ومشـكلات التواصـل الاجتماعى لنموذج الحياة وهى عناصـر أو بالأحرى

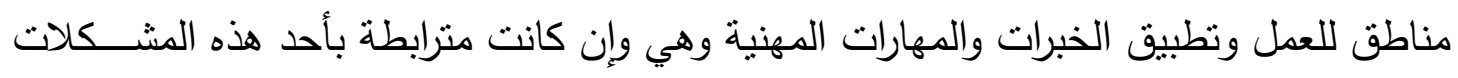

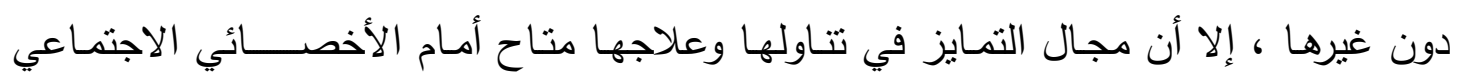
ومؤسسـة الخدمة الاجتماعية العاملة في هذا النطاق حسب النسب السياسـات العلمية والفروق الفردية.

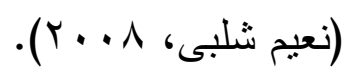

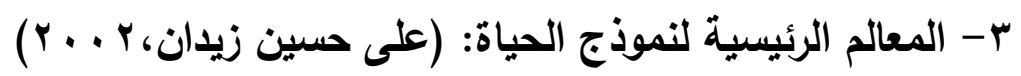
- تمثل دائرة علاقات الانسان وارتباطه الخاصة ضرورة بيولوجية واجتماعية له خلال مراحل حياته

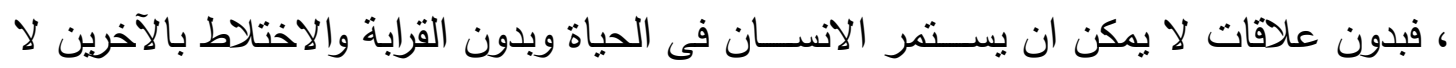

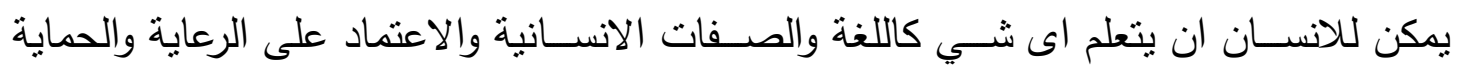

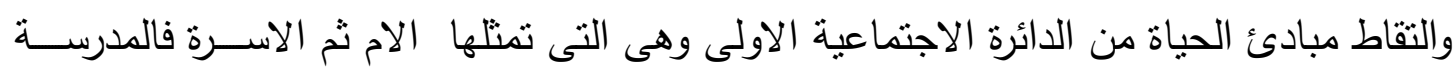
وجماعة الاصدقاء ومختلف المؤسسات والتتظيمات. - متأتى الهويـة identity وتقدير الذات من العلاقات مع الاخرين ابتداء من الدائرة الاجتماعية

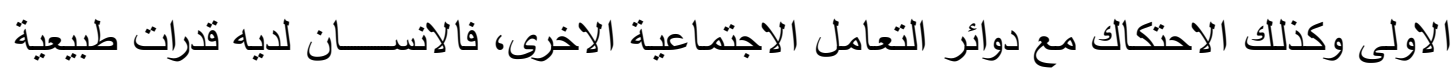

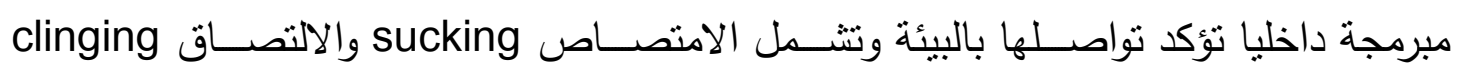


والتأصل rooting he flexes بالإضـافة الى شكل الانسان ومواصفاته العضوية وحساسيته التى تمثل مكونات اولية لشخصيته فيما بعد. - الكفاءة competence فانها تمثل الرابطة الثـخصية والتوجه الذاتى والانتماء وتشـير الى حجم الخبرات الناجمة فى اطار البيئة، كما انها تمنل حافزا داخلى يدفع الانســـان الى محاولة التغلب على الصـوبات التى تواجهه اثتاء تفاعله مع البيئة ، وبالطبع فهى مهمة شـاقة ولكنها ضـرورية لتأكبد الذات.

\section{ع - مراحل وخطوات العمل بنموذج الحياة مع كبار السن:}

المرحلة الأولية: الاستعداد والتهيؤ:

- ـ وفيها تقوم الباحثة بإعداد نفســها لكيفية اقتحام حياة كبار الســن قبل المواجهة الحقيقية للحقائق غير الموضــوعية في حياتهم، كما تقوم الباحثة بتقييم أهداف كبار السـن من خلال تقييم حقيقة المواقف التى يعانون منها وتسبب عدم دمجهم اجتماعياً مع الآخرين في الأسرة والدار والمجتمع. - - في هذه المرحلة قامت الباحثة بتطبيق مقياس الدمج الاجتماعى لكبار الســن على المســـنين المقيمين بالدار ممن تتطبق عليهم شـروط العينة وتم تحديد أثـكال عدم الدمج الاجنماعى (مع الع الأسـرة- الدار - المجتمع) وكذلك تم تحديد الأدوار والمهام لكل من الباحثة وكبار السـن، وكذللك الأساليب العلاجية اللازمة لتحقيق أهداف البرنامج المهنى. وتتحدد هذه المرحلة إجرائياً فيما يلى:

ا- قامت الباحثة بالاسـتعداد والتهيئة من خلال فهم طبيعة وخصـائص كبار السـن المقيمين بالدار بصفة عامة وأسباب وعوامل عدم إندماجهم اجتماعياً مع الآخرين من خلال الاطلاع على التراث النظرى الخاص بكبار السن.

ץ- التعاقد المهنى وتحديد أدوار كل من الباحثة والمسـن شـاهة وكذلك الأسـاليب العلاجية المناسـبة التى تم اختيارها من النماذج العلاجية الأخرى والتى تســــه بشــــل واضــــح في تعزيز الدمج الاجتماعى لكبار السن في محيط الأسـرة أو في المؤسسـة المخصصـة لرعايتهم أو مع الأنساق

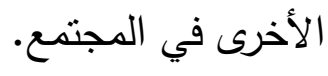
المرحلة الثانية: مرحلة التذخل:

وفيها تقوم الباحثة بمســـاعدة المســن على القيام بـالأعمال والمهام المطلوبـة منهـ خلال المراحل والتحولات في حياته، وهنـا تركز البـاحثة على فاعليـة الخبرة والمهارات في مواجهة المســن لاحتبـاجـاته 
ومشـكلاته وما يتطلبه ذلك من مرونة في علاقات المسـن المختلفة داخل وخارج الأسـرة، والأنشـطة المختلفة الأخرى كالمشـاركة في الجمعيات والمنظمات الاجتماعية، ودمج المسـن اجتماعياً مع الأنسـاق الأخرى من خلال البرامج والمشروعات والأنشطة المختلفة كالرحلات والندوات الدينية والحفلات والمعسكرات التى تتظمها دور الايواء.

وتستلزم هذه المرحلة استخدام الأساليب الفنية وفق متطلبات النموذج والأساليب العلاجية التى تتاسب تعزيز الدمج الاجتماعى لكبار السـن مع الأنسـاق المختلفة مثل الاتصـال والعلاقة المهنية، والاسـتبصـار،

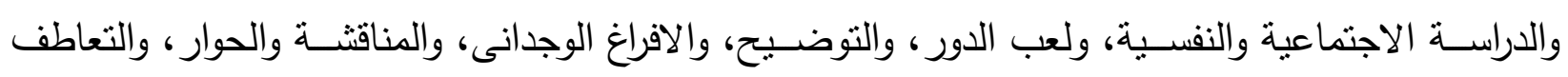
والحكمة والسيكودراما. المرحلة الثالثة: مرحلة الانهاء: وفيها تســتـعد الباحثة لتنفيذ جزء مهم من البرنامج وهو إنهاء العلاقة وطالما أن هذه المرحلة عميقة وطوبلة بين الباحثة والمسن فقد تتضمن ردود أفعال كثيرة للوصول إلى نقطة تلاقى بين الباحثة والمسن، وهذه المرحلة يتم فيها عملية التقييم لتحديد أثز الجهود التى بذلتها الباحثة والمسن فهى نهاية لمعاناة المسن وبداية لعلاقات وتفاعلات اجتماعية بينه وبين البيئة الطبيعية والاجتماعية باسلوب سوى ودون مشاكل. وفى هذه المرحلة قامت الباحثة بتقييم العمل المهنى وكذلك التدخل المهنى من خلد البرنامج تزكز على ضــرورة وجود تباعد بين المقابلات المهنية مع كبار الســن للتأكيد على اسـتـمرار العلاقة المهنية لفترة زمنية تحددها الباحثة وفقاً لظروف كل حالة حتى لا تؤدى إلى حدوث انتكاسـة للمسن وعرقلة العلاقة المهنية بين المسن والباحثة. 0- المهارات المهنية المطلوبة في برنامج التذخل المهنى: قامت الباحثة بالتركيز على اســـتخدام مجموعة من المهارات المهنية خلال تطبيق برنامج التذخل المهنى للدراسة كالتالى : - - مهارة التفكير النقدى: والتى تتطلب إعادة تتظيم المسن لنفسه لتحقيق الدمج الاجتماعى لله. - مهارة الملاحظة: من خلال ملاحظة الباحثة لكبار السـن وتصـرفاتهم أثثاء تواجدها معهم بالدار وأثتاء تفاعلاتهم مع الآخر ين وردود أفعالهم وأفعال الآخرين المحيطين بهم والتى تبين مدى القدر الذى يتمتعون به دن الدمج الاجتماعى. 
- مهارة الاتصـال: وذلك من خلال مسـاعدة الباحثة لكبار السـن على فتح قنوات الاتصـال المغلقة بينهم وبين الآخرين من الزملاء بالدار ، وأفراد أسرهم، والمحيطين بهم في المجتمع، وذلك يسـاعد على تعزيز الدمج الاجتماعى لهم. - مهارة المناقثــة والحوار : وذللك من خلال قيام الباحثة بتهيئة كبار السـن للحوار والمناقثـة حول مشــاركتهم في الأنثــة والبرامج التى تقدمها الدار وتثـــيعهم على المشــاركة لتعزيز دمجهم اجتماعيا مع زملائهم والتواصل مع بعض أفراد أسرهم المنقطعين عن زيارتهم بالدار . - مهارة اتخاذ القرارات: من خلال قيام الباحثة بتوضيح أهمية تحمل المسئولية من قبل كبار السن وذلك بإتخاذ القرارات الهامة المتعلقة بشـون حياتهم في المشـاركة في الأنشطة الحياتية المتتوعة التى تقدمها الدار وذلك للوصــول إلى حالة من الاسـتقرار والدمج الاجتماعى مع الآخرين بالدار والمجتمع المحيط بهم. - مهارة إقامة علاقات اجتماعية جديدة: من خلال قيام الباحثة بمساعدة كبار السن المقيمين بالدار على إقامة شبكة من العلاقات الاجتماعية الجديدة مع الزملاء ومع أبناءهم وأحفادهم وذلك يحقق دعماً ودمجاً اجتماعياً لهم.

צ- الأدوار المهنية المستخدمة في برنامج التدخل المهنى وفق نموذج الحياة: تتحدد الأدوار المهنية التى تم قيام الباحثة بها مع كبار السـن وأسـرهم والمحيطين بهم في المجتمع خلال برنامج التدخل المهنى وفق نموذج الحياة في خدمة الفرد لتعزيز الدمج الاجتماعى لهم فيما يلى: - - دور الممكن: حيث قامت الباحثة ببعض الأعمال بهدف تحسين وتقوية دوافع كبار السـن المقيمين بالدار لتعزيز دمجهم اجتماعياً من خلال التعاون والمشاركة مع الآخرين بالدار في الأنشطة والبرامج الاجتماعية التى تنفذها الدار . - - دور المعلم: من خلال قيام الباحثة بتعليم كبار السن كيف تتمو علاقاتهم الاجتماعية الايجابية مع الزملاء وأفراد أسرهم والآخرين في المجتمع وتعديل بعض اتجاهاتهم السلبية تجاه أبناءهم. - - دور الوسـيط: حيث قامت الباحثة بدور الوسـيط بين كبار السـن والمحيطين بهم من الزملاء بالدار وأفراد أسـرهم والانســاق الأخرى في المجتمع لتحسـين العلاقات الاجتماعية معهم وكيف يمكن لهم من تحقيق المشاركة والاندماج الاجتماعى المرغوب مع هذه الانساق المختلفة. - - دور المسـاعد: من خلال قيام الباحثة بتقديم كافة أسـاليب المسـاعدة المباشـرة وغير المباشـرة لكبار السـن على مستوى الدار والأسرة والمجتمع لتعزيز عمليات وآليات الدمج الاجتماعى لديهح مع هذه المستويات. 
- - دور المرشـد: حيث قامت الباحثة بتقديم مجموعة من الإرشـادات لتوجيه كبار السـن من منطلق حاجاتهم إلى مزيد من فرص تكوين العلاقات الاجتماعية والمشـاركة والتعاون مع الآخرين في الأسـرة ودار الايواء والمجتمع وتتحدد هذه الإجراءات الإرشادية على النحو التالى: ا- الاجراءات الارشادية على مستوى الأسرة:

- مســاعدة كبار السـن على الاثــتراك فى بعض الأعمال والأدوار البسـيطة التى تتاسـب قدراتهم داخل أسرهم.

ـ العمل على عدم إحســاس كبار الســن بالتجاهل أو الاهمال من قبل باقى أفراد الأســرة الذين يعيشون ويقيمون معهم.

- إتاحة الفرص لاسـتشـارة كبار السـن فى بعض الأمور الهامة فى الأسـرة ومســاهمتهم فى اتخاذ قرارات بشأنها. - العمل على الاكتساب من خبرات كبار السن والاستفادة منها فى محيط الأسرة. - تعزيز امكانات الأسرة بصفتها المحيط الطبيعى والبيئة الداعمة والمشجعة لكبار السن فيها وتقبل التغيرات لايهح والتكيف معها. - الاهتمام الأسرى بكبار السن وحرص الأسرة على رعاية مسنيها وتوفير الخدمات اللازمة لهم فى هذه المرحلة العمربة بإعتبارها حق لهم. ـ الاهتمام بعمليات الدمج الاجتماعى لكبير السـن فى ظل عائلته حتى يثـعر أنه فرد له نصـيب كامل فى أسرته. - العمل على تعزيز الدمج الاجتماعى لكبار السن مع أحفادهم فى محيط الأسرة. r- الاجراءات الارشادية على مستوى المؤسسات المخصصة لرعايتهم:

- ضرورة ايجاد نظام جديد يسمح لكبار السن بالمشاركة فى إدارة المؤسسة المخصصة لرعايته. - اشتراك المسن فى تخطيط وتقويم البرامج التى تتفذ فى المؤسسة. - الاشتراك من قبل كبار السن فى تقديم الخدمات والبرامج داخل هذه المؤسسات. - قيام المؤسسات غير الحكومية ومؤسسـات المجتمع المدنى بالمساهمة فى إدراج خدمات وبرامج رعاية كبار السن ضمن برامجها حتى يمكن الاستفادة من جهودها فى تقديم أفضل خدمات لتلك 
- استحداث مؤسسـات رعاية كبار السن أسـاليب علاجية غير تقليدية ذات طابع اجتماعى لتعزيز

$$
\text { الدمج الاجتماعى للمسنين منل اسلوب الحكمة- لعب الأدوار - السيكودراما. }
$$

"- الاجراءات الإرشادية على مستوى المجتمع:

- المســاهمة فى توعية أفراد المجتمع باحتياجات كبار السـن وكيفية مســاعدتهم إلى جانب تتمية وتدعيم العلاقات بين التخصـصـات العاملة فى مجال رعاية كبار السـن وبين المسـنين أنفسـهم لزيادة دمجهم اجتماعياً.

ـ الاهتمام المجتمعى بحقوق كبار السـن وسـن التشـريعات الخاصــة بالعمل أو التأمينات لحماية المسـنين وتقديم خدمات متعددة يحتاجون إلبها وفق الأسـس والقواعد التى حددتها أغلب دسـاتير الدول العربية. - قيام المجتمعات العربية بتفعيل القيم الدينية التى تحث الأبناء على رعاية الآباء وحماية المسـنين خاصة الذين فقدوا أسرهم وليس لهم عائل لرعايتهم كمسئولية أخلاقية تجاه كبار السن. - العمل على تثــيع مشــاركة الثــباب فى توفير الخدمات اللازمة لكبار الســن داخل الجهات المهتمة بشئون المسنين وذلك لتوثيق دمج العلاقات الاجتماعية بين الأجيال. - العمل على إيجاد وســـائل عمل ناجحة للاســـفادة من حكمة وخبرة كبار الســـن مع توعيتهم بمسئوليتهم تجاه الاجيال اللاحقة. - مسـاعدة كبير السـن على العيش فى ظل المجتمع وأن يحيا فى صـحة وطمأنينة، ويثـعر بأنه انسان له قيمة وكرامة فى المجتمع. - وضع سياسات وبرامج عملية تهدف إلى صبانة التضامن الاجتماعى والاقتصادى لإعطاء كبار السن الإمكانية اللازمة للمساهمة فى تتمية المجتمع.

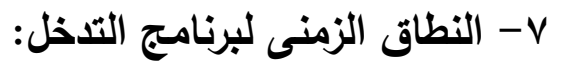
اســـتغرق تطبيق برنـامج التدخل المهنى بـاســتــدام نموذج الحيـاة في خدمـة الفرد لتعزيز الدمج

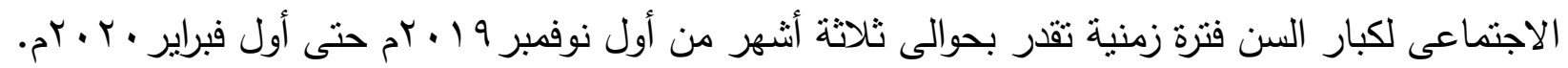
- استراتيجية التجريب في هذه الاراسة: قامت الباحثة بتحديد اسـتراتيجية التجريب المسـتخدمة في هذه الدراسـة معتمدة على المعايير العلمية التى يمكن من خلالها التحكم قدر الإمكان في متغيرات الدراسـة مع الأخذ في الاعتبار التداعيات التى تتعلق هي بالمتغيرات الاجتماعية على النحو التالى: 
- تحديد خصـائص إطار المعاينة من خلال اختيار مفردات عينة الدراسـة بشـرط توافر عنصـر التجانس بين هذه المفردات. - تصـميم أداة القياس الرئيسية التى تتناسـب مع دراسـة هذا الموضـوع والتى اثـتملت على مقياس تعزيز الدمج الاجتماعى لكبار السن المقيمين بدار الحنان والتكربم لرعاية وايواء المسنين. - تحديد الأسـاليب الاحصـائية المناسـبة لتقدير دلالة التغيرات التى تحدث نتيجة اسـتخدام نموذج

الحياة مع كبار السن لتعزيز دمجهم اجتماعياً وتحليل وتفسير النتائج التى تم التوصل إليها. - قامت الباحثة بتطبيق اسـتراتيجية التجريب في هذه الدراسـة وفق الأسـاليب والأدوار والمهارات الفنية والمهنية لطريقة العمل مع الأفراد والتى تتناســب مع المعطيات النظرية لنموذج الجياة في هذه الدراسة.

المبحث الثالث: عرض ومناقشة نتائج الدراسة: لاختبار الفرض الأول والذى ينص على أنه : "يوجد فرق دال إحصـــائياً بين متوســــى رتب درجات التطبيقين القبلى والبعدى لبعد تعزيز الدمج الاجتماعى لكبار السن فى محيط الأسرة لصالح التطبيق البعدى." استخدمت الباحثة اختبار ويلككسون Wilcoxon Test للمجموعات المرتبطة، ويوضح جدول (1 ( ) نتائج هذا الفرض:

جدول (11)

نتائج اختبار ويلككسون للتطبيقين القبلى والبعدى لبعد تعزيز الدمج الاجتماعى لكبار السن فى محيط الأسرة

\begin{tabular}{|c|c|c|c|c|c|c|}
\hline مستوى & ويلككسونة & الرتب & متوسط الرتب & العدد & الرتب & المتغير \\
\hline \multirow{4}{*}{$\cdot, \cdot 1$} & \multirow{4}{*}{$r, r-$} & 1 & 1 & 1 & السالبة & \multirow{4}{*}{ الامج فى محيط } \\
\hline & & 119 & $\Lambda, 0$ & $1 \varepsilon$ & الموجبة & \\
\hline & & - & - & • & المتساوية & \\
\hline & & - & - & 10 & المجموع & \\
\hline
\end{tabular}

يتضح من الجدول السابق أن قيمة " Z " دالة إحصائياً عند مستوى ا .,. • مما يشير إلى وجود فرق بين متوسطى رتب درجات التطبيقين القبلى والبعدى لبعد تعزيز الدمج الاجتماعى لكبار السـن فى محيط الأسـرة

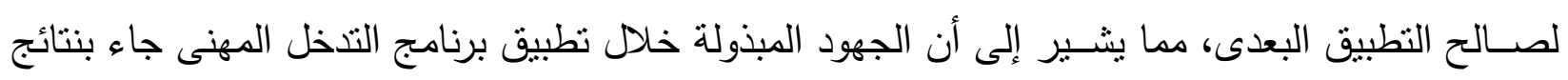




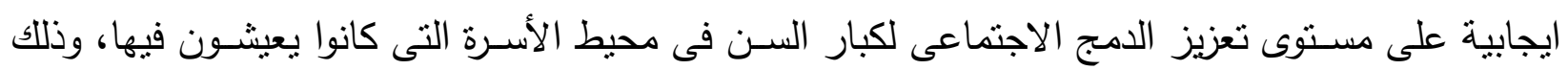
يوضح فعالية استخدام نموذج الحياة فى خدمة الفرد فى تعزيز الدمج الاجتماعى لكبار السن مع أسرهم.

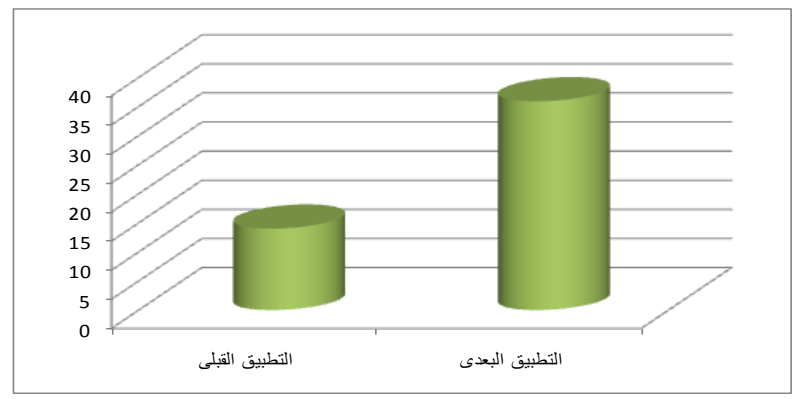

شكل (1) ش (1)

رسم بيانى لمتوسطى درجات التطبيقين القبلى والبعدى

لبعد تعزيز الامج الاجتماعى لكبار السن في محيط الأسرة

يبين الرسـم البيانى السـابق شكل رقم(1 ) مدى الاتسـاق مع نتائج جدول رقم( (1 ) حيث يوجد فروق

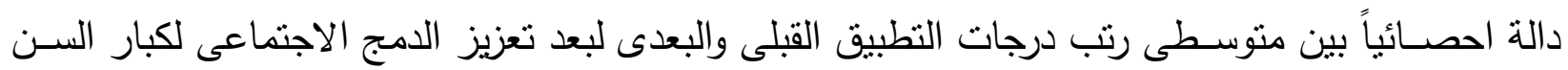

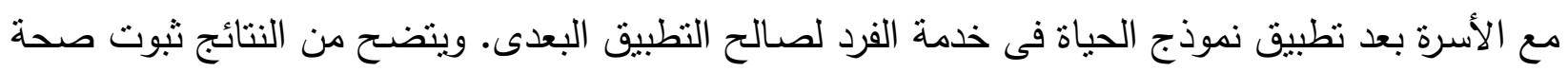

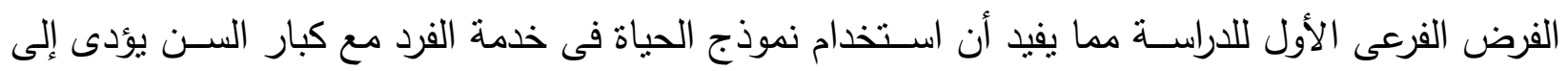
تعزيز الدمج الاجتماعى لهم مع أسرهم.

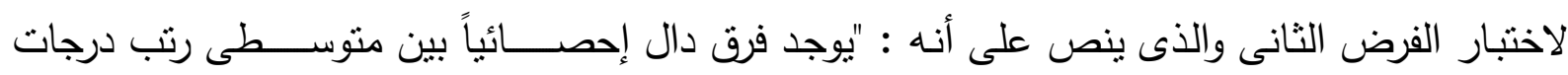

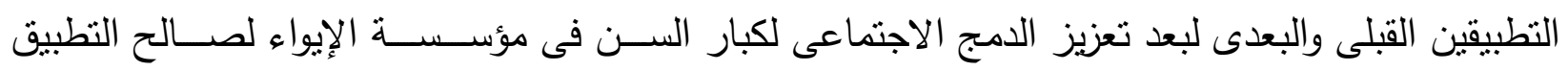

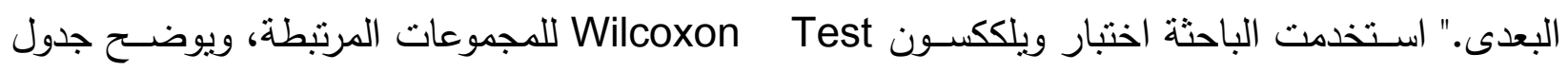

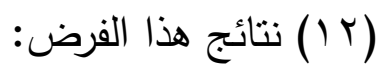




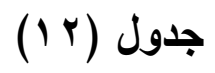

نتائج اختبار ويلككسون للتطبيقين القبلى والبعدى لبعد تعزيز الدمج الاجتماعى لكبار السن فى مؤسسة الإيواء

\begin{tabular}{|c|c|c|c|c|c|c|}
\hline الدلالة & ويلكسونة & الرجب & متوسط الرتب & العدد & الرتب & المتغير \\
\hline \multirow{4}{*}{$\cdot, \cdot 1$} & \multirow{4}{*}{$r, 1-$} & . & . & . & السالبة & \multirow{4}{*}{ مؤسسة الإيوج فى } \\
\hline & & 91 & v & ir & الموجبة & \\
\hline & & - & - & $r$ & المتساوية & \\
\hline & & - & - & 10 & المجموع & \\
\hline
\end{tabular}

يتضح من الجدول السابق أن قيمة " Z " دالة إحصائياً عند مستوى ا .,. • مما يشير إلى وجود فرق بين متوسطى رتب درجات النطبيقين القبلى والبعدى لبعد تعزيز الدمج الاجتماعى لكبار السن فى مؤسسة الإيواء

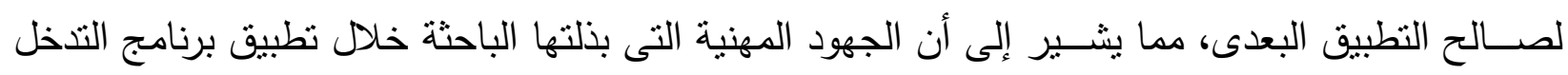

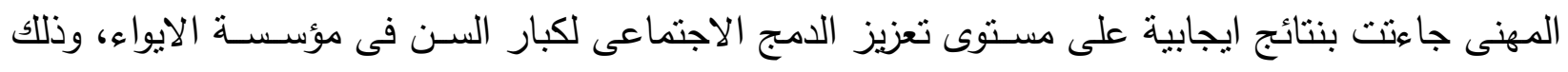

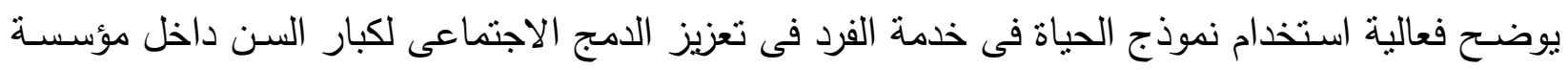
الايواء التى يعيشون فيها.

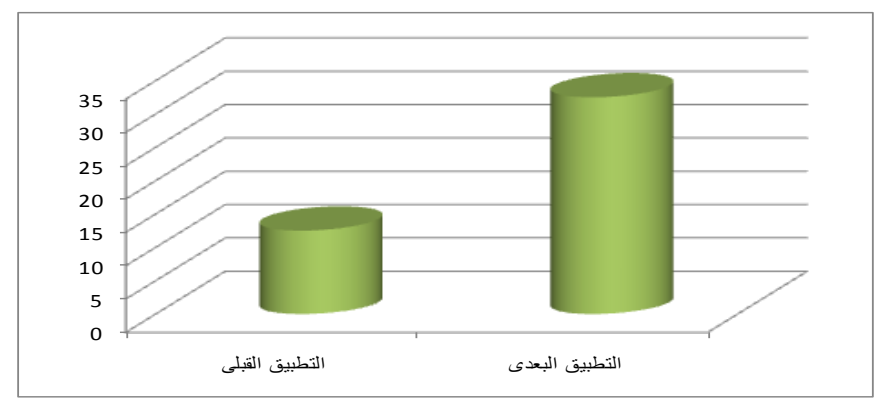

شكل (r)

رسم بيانى لمتوسطى درجات التطبيقين القبلى والبعدى

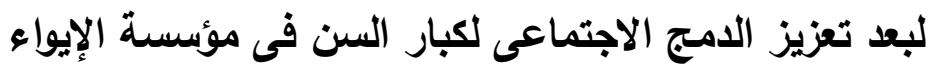

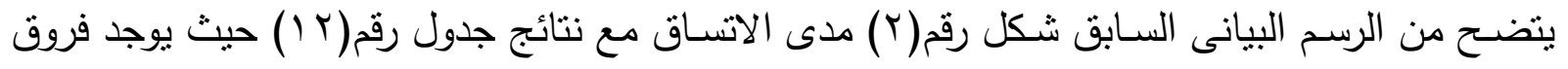

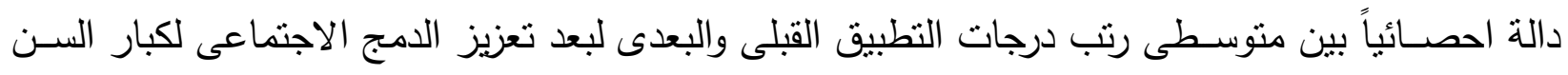


مع المؤســـة بعد تطبيق نموذج الحياة فى خدمة الفرد لصـالح التطبيق البعدى. ويتضـح من النتائج السـابقة ثبوت صـة الفرض الفرعى الثانى للاراسـة مما يفيد أن استخدام نموذج الحياة فى خدمة الفرد مع كبار السن المقيمين بدور الايواء يؤدى إلى تعزيز الدمج الاجتماعى لكبار السن مع المؤسسة. لاختبار الفرض الثالث والذى ينص على أنه : "يوجد فرق دال إحصــــائياً بين متوســـــى رتب درجات التطبيقين القبلى والبعدى لبعد تعزبز الدمج الاجتماعى لكبار الســـن فى المجتمع لصـــالح القياس البعدى." استخدمت الباحثة اختبار ويلككسون Wilcoxon Test للمجموعات المرتبطة، ويوضح جدول (س I) نتائج هذا الفرض:

$$
\text { جدول (r) }
$$

نتائج اختبار ويلككسون للتطبيقين القبلى والبعدى لبعد تعزيز الامج الاجتماعى لكبار السن فى المجتمع

\begin{tabular}{|c|c|c|c|c|c|c|}
\hline الدلاكة & ويلككسونة & مجموع الرتب & متوسط & العدد & الرتب & المتغير \\
\hline \multirow{4}{*}{$\cdot, \cdot 1$} & \multirow{4}{*}{ r,r - } & - & - & - & السالبة & \multirow{4}{*}{ الامج فى المجتمع } \\
\hline & & 1.0 & $v, 0$ & $1 \varepsilon$ & الموجبة & \\
\hline & & - & - & 1 & المتساوية & \\
\hline & & - & - & 10 & المجموع & \\
\hline
\end{tabular}

يتضـح من الجدول السـابق أن قيمة " Z " دالة إحصـائياً عند مستوى I ., • مما يشير إلى وجود فرق بين متوسطى رتب درجات التطبيقين القبلى والبعدى لبعد تعزيز الدمج الاجتماعى لكبار السن فى المجتمع لصالح التطبيق البعدى. مما يثـــير إلى أن الجهود المهنية التى بذلتها الباحثة خلا تطبيق برنامج التذخل المهنى جاء بنتائج ايجابية على مســتوى تعزيز الدمج الاجتماعى لكبار الســن فى المجتمع. وذللك يوضــح فعالية استخدام نموذج الحياة فى خدمة الفرد فى تعزيز الدمج الاجتماعى لكبار السن مع المجتمع. 


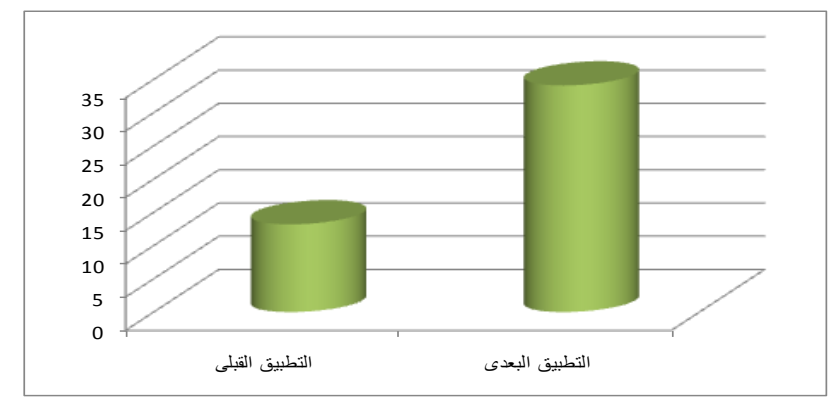

شكل (r)

رسم بيانى لمتوسطى درجات التطبيقين القبلى والبعدى

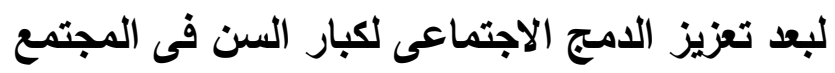

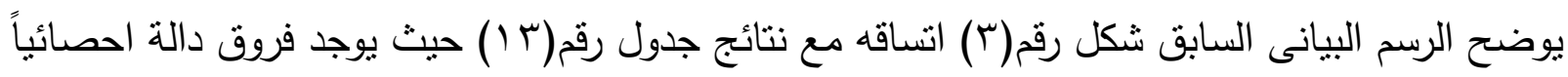

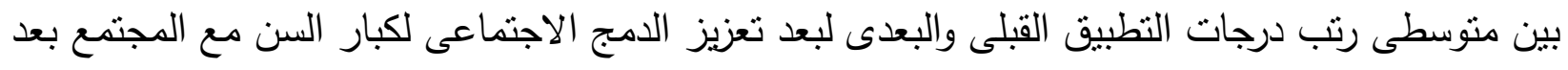
تطبيق نموذج الحياة فى خدمة الفرد لصالح التطبيق البعدى.

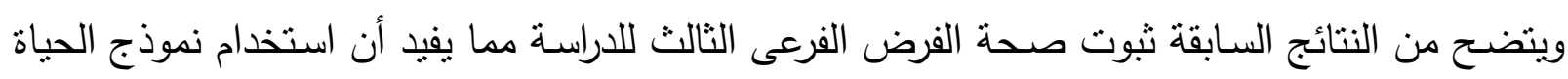
فى خدمة الفرد مع كبار السن يؤدى إلى تعزيز دمجهم اجتماعياً مع المجتمع.

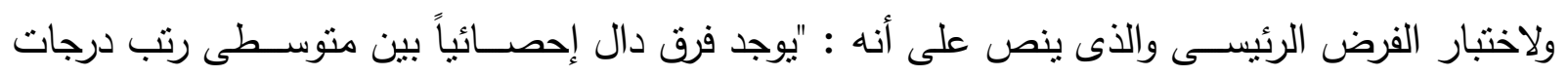

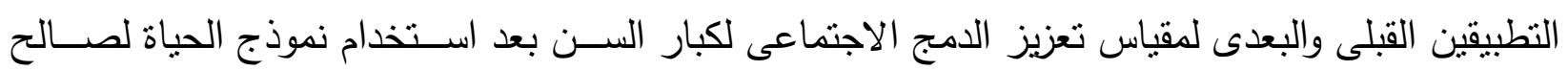

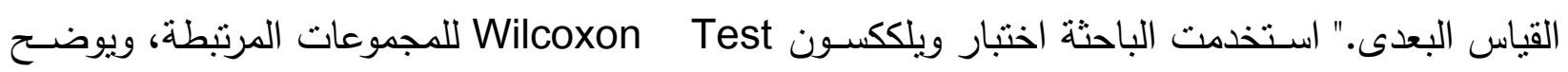
جدول (ع () نتائج هذا الفرض: 
جدول ( 1 ( )

نتائج اختبار ويلككسون للتطبيقين القبلى والبعدى لمقياس تعزيز الدمج الاجتماعى لكبار السن

\begin{tabular}{|c|c|c|c|c|c|c|}
\hline مستوى & ويلككسونة & الرتب & متوسط & العدد & الرتب & المتغير \\
\hline \multirow{4}{*}{$\cdot, \cdot 1$} & \multirow{4}{*}{$r, \varepsilon-$} & . & . & . & السالبة & \multirow{4}{*}{ الاجتماعى لكبار الامج } \\
\hline & & Ir. & $\Lambda$ & 10 & الموجبة & \\
\hline & & - & - & . & المتساوية & \\
\hline & & - & - & 10 & المجموع & \\
\hline
\end{tabular}

يتضح من الجدول السابق أن قيمة " Z " دالة إحصائياً عند مستوى ا .,. • مما يشبر إلى وجود فرق بين

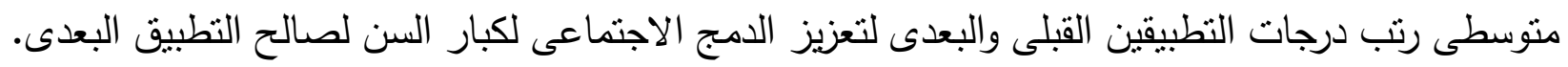
وذللك يثـير إلى أن الجهود المبذولة خلال تطبيق برنامج التنخل المهنى جاءت بنتائج ايجابية لصسالح تعزيز الدمج الاجتماعى لكبار السـن المقيمين بدور الايواء. وذللك يوضـح فعالية اسـتخدام نموذج الحياة فى خدمة

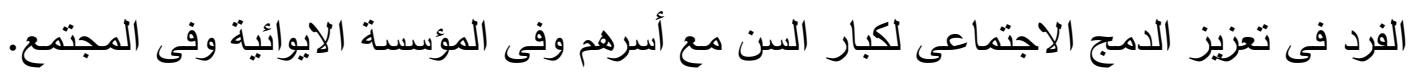

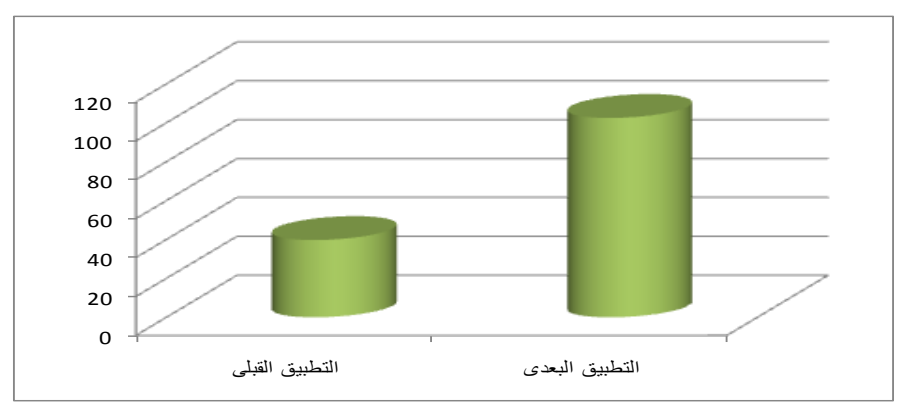

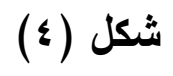

رسم بيانى لمتوسطى درجات التطبيقين القبلى والبعدى

لمقياس تعزيز الامج الاجتماعى لكبار السن

يتسق الرسم البيانى السـابق شكل رقم(ع ) مع نتائج جدول رقم(ع ( ) حيث يوجد فروق دالة احصـائياً

بين متوسـطى رثب درجات التطبيق القبلى والبعدى للامج الاجتماعى لكبار السـن بعد تطبيق نموذج الحياة فى خدمة الفرد لصالح التطبيق البعدى. وتشير النتائج السابقة ثبوت صحة الفرض الرئيسى للاراسة مما يفيد 
أن اسـتخدام نموذج الحياة فى خدمة الفرد مع كبار السـن يؤدى إلى تعزيز الدمج الاجتماعى لهم مع الأسـرة والمؤسسة والمجتمع. 


\section{المراجع المستخدمة}

1. عبد الحميد عبد المحسن: الخدمة الاجتماعية فى مجال رعاية المسنين فى الوطن العربى، دار الثقافة

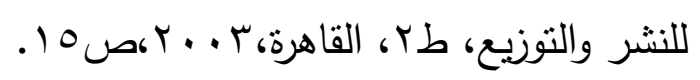

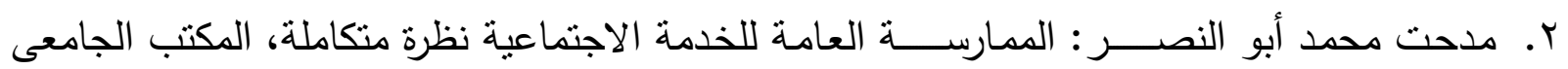

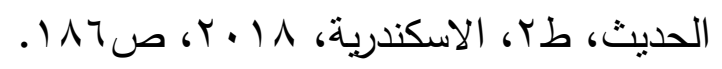

مدحت محمد أبو النصـر : الممارسـة العامة للخدمة الاجتماعية في مجال رعاية كبار السن (

$$
\text { المنصورة : المكتبة العصرية ، } 9 \text { ( • ب ). }
$$

3. Germailn B. Carl: Alex Gitterman: Ecological perspective, in encyclopedia of social workm $19^{\text {th }}, \mathrm{v}(1)$, NAWS, press, 1995, p:21.

4. Payne Maleon: modern social work theory, second edition, London, Macmillan, press LTP, 1997, p:143.

ه. ســامية عبد الرحمن همام : فعالية نموذج الحياة في خدمة الفرد في علاج المشــكلات الاجتماعية

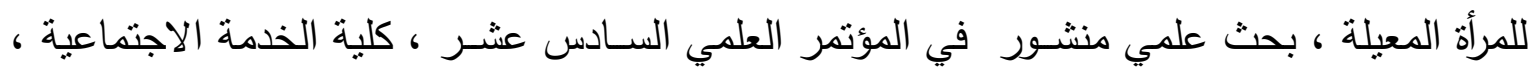

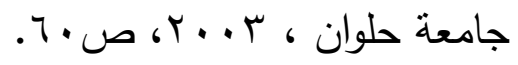
7. اميره بخش: فاعلية اسلـوب الذمج على مفهوم الذات والاسـلوب التكيفى لدى الأطفال المتخلفين عقلياً

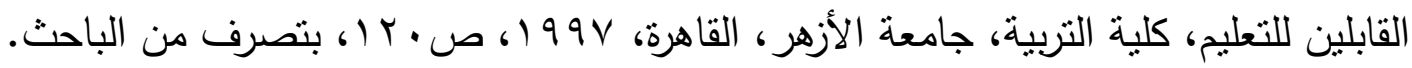

7. Lewis, B, Rena \& Door Lag, H, Donald: teaching special students in the main streaming second edition, merril publishing company, U.S.A., 1987, p:19. ^. خولة يحيى: البرامج التربوية لذوى الاحتياجات الخاصـة، دار الميسره للنشر والتوزيع، عمان، الأردن،

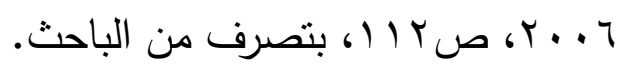
9. إلياس أنطون إلياس : قاموس الياس العصــري ( انجليزي - عربي ) القاهرة دار الياس العصــرية ،

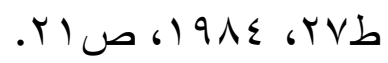

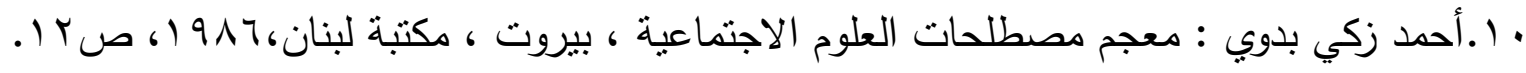

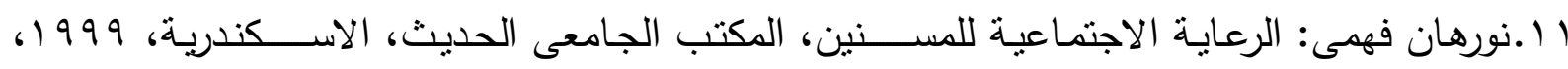


r ا.عزت حجازي : خطة العمل للمسـنين ، المؤتمر الأول ، و-با مايو ، البحوث الاجتماعية ، المجلد الثاني ، المركز القومي للبحوث الاجتماعية ، القاهرة، 999 (،ص . . ب. با .عادل موسى جوهر : العوامل الاجتماعية والنفسية التي نؤدي للتسول والدور المقترح لخدمة الفرد في مواجهتها - دراســـة مقارنة بين فئتي الأحداث وكبار الســن ، المؤتمر العلمي الثاني ، كلية الخدمة

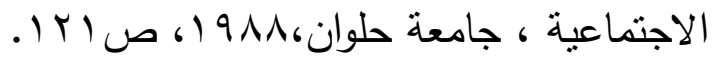

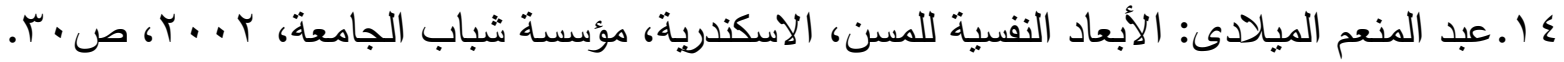
ا ـسامية عبد الرحمن همام : فعالية نموذج الحياة في خدمة الفرد في علاج المشكلات الاجتماعية للمرأة المعيلة ، بحث علمي منشور في المؤتمر العلمي السـادس عشر ، كلية الخدمة الاجتماعية ، جامعة

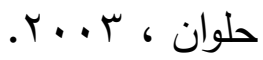
7 ا .صـفاء عادل مدبولى: ممارسـة نموذج الحياة في التخفيف من حدة مشـكلة الاغتراب الزواجى، مجلة دراسات الخدمة الاجتماعية والعلوم الانسانية، القاهرة، جامعة حلوان، العدد ج (، ابريل؛ ـ. . . . V ا ـ عبد الناصـف يوسـف شـومان : فعالية نموذج الحياة في خدمة الفرد في التخفيف من حدة الضـغوط الحياتية لدى المسن ، بحث علمي منشور ، مجلة دراسات في الخدمة الاجتماعية والعلوم الانسانية ، كلية الخدمة الاجتماعية ، جامعة حلوان ، العدد Y V ، الجزء الثاني ، أكتوبر ع . . r. ^ ا ـصفاء محمد أمين محمد: العلاقة بين ممارسة نموذج الحياة في خدمة الفرد والتخفيف من حدة الخجل الاجتمـاعى لتلميذات المرحلة الاعداديـة، المؤتمر العلمى الثامن عثــر، كلية الخدمة الاجتمـاعية،

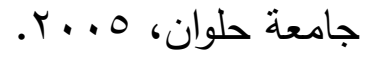

9 ا ـفاتن محمد عامر : ممارســـة نموذج الحياة في خدمة الفرد لتتمية المســـولية الاجتماعية لدى أطفال الثوارع، المؤتمر العلمى الدولى العثرون، كلية الخدمة الاجتماعية، جامعة حلوان، V . . . . • •.ابتسـام رفعت محمد ادريس: استخدام نموذج الحياة في خدمة الفرد وتحسين نوعية الحياة لكبار السن المســاء إليهم، المؤتمر العلمى الثانى، المسـنون في الأسـرة العربية بين الثوابت الاقليمية والمتغيرات العالمية، المعهد العالى للخدمة الاجتماعية بالاشتراك مع منظمة الدول العربية ومنظمة الأسرة العربية،

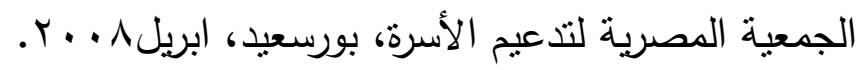
ا ا.نعيم عبد الوهاب شـــلبى: اســـتخدام نموذج الحياة في خدمة الفرد للتخفيف من حدة الاضــــرابات الاجتماعية والنفســية للمســنين المقيمين بدور الايواء بمحافظة بورســـيد، المؤتمر العلمى الثانى، المســـون في الأســـرة العربيـة بين الثوابـت الاقليميـة والمتغيرات العـالميـة، المعهد العـالى للخدمـة 
الاجتماعية ببورسـعيد بالاثـتراك مع منظمة الدول العربية ومنظمة الأسـرة العربية والجمعية المصـرية

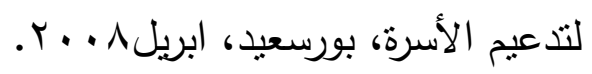

r r.نوره رشـى عبد الواحد: فعالية التدخل المهنى بنموذج الحياة في التخفيف من حدة سـوك العنف لدى

الفتيات في المؤسـســات الايوائية، بحث منشـور في مجلة دراســات في الخدمة الاجتماعية والعلوم

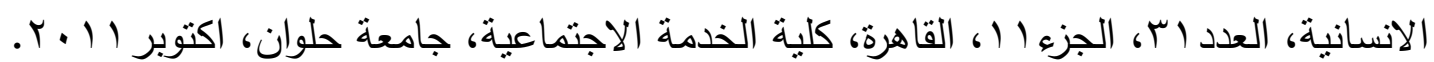

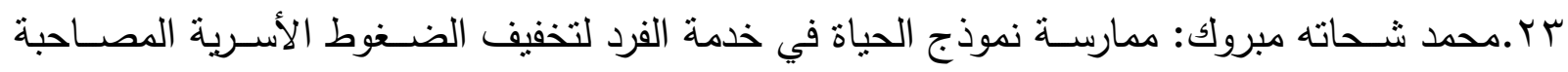

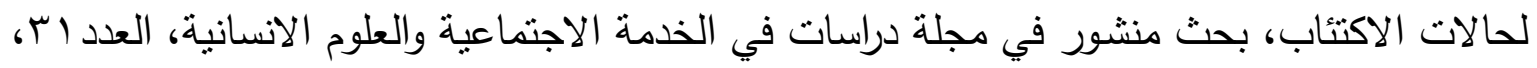

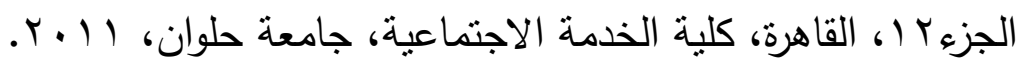

24. Oliver K. Schilling and Werner Hans Wahl, modeling late- life adaptation in affective well- being under a severe chronic Health condition. The case of Age- Related Macular American Psychological Association. Vol 21(4), 2006,p:703.

25. Rodney B. Dieser : Across - cultural critique of Newer determination and enjoyment enhancement model, Aristotelian good life model, and the optimizing lifelong Health through therapeutic recreation model, therapeuticRecreation Journal, vol 36 (4),2008, p:352.

26. Dennis Raphael . etal: Factoranalytic properties of the quality of life profile : Examination of the nine subdomain quality of life model psychological Reports, vol 88 (1),2009, p:265.

27. Herbert C. Covey :old age portrayed by the ages of life model from the middle ages to the $16^{\text {th }}$ century. Journal Gerontological society of America , vol 29 (5),2010,p:692.

28. Carel B. Germain and Alex Gitterman : The life model of social work practice, New York, Columbia university press, $2^{\text {nd }}$ ed $.2010, p: 490$.

29. Alex Gillerman : Life model theory and social work treatment, New York, US, free press, $4^{\text {th }}$ ed, $2013, \mathrm{p}: 738$. 
30. Alice Gall Miller : A study of the life model of practice in a residential treatment program for adolescents, PHd, University of Maryland at baltinore, 2015, p205.

آس.اقبال الامير السـمالوطى: نحو رؤية تتميوة لمواجهة مشـاكل المسنين، دراسـة ميدانية، بحث منشـور،

مجلة القاهرة للخدمة الاجتماعية، العدد الأول، المعهد العالى للخدمة الاجتماعية بالقاهرة، .99 19. r.r.ثريا جبريل: المشاكل التى يعانى منها المسنين في المملكة العربية السعودية ودور الخدمة الاجتماعية

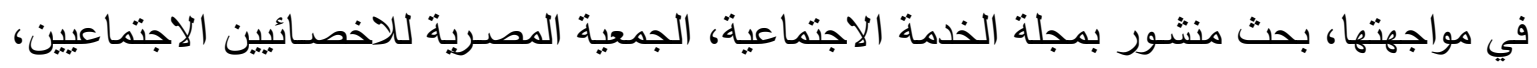

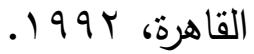

33. Bacom, Victoria: acomparative analysis of life stress for elder entering long term care, facilities elderly living in the community, PH.D.Dis, abst, norlheastern university, 1992.

§ ז.رفعت عبد الباسط محمد: سياسات الرعاية الاجتماعية للمسنين، دراسة مشكلات واحتياجات المسنين،

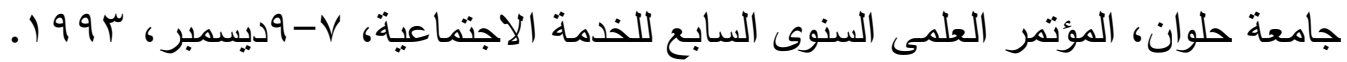
هـ.حنان حسـن جمعه: دراسـة وصـفية مقارنة للمشكلات الاجتماعية والنفسية للمسنين فى دور الرعاية الايوائية والمترددين على نوادى المسـنين، رسـالة ماجسـتير غير منشـورة، كلية الخدمة الاجتماعية ، جامعة حلوان، القاهرة، 99 1. جr.على أحمد الطراح: قضــايا ومشـكلات المسـنين بمجتمعات التعاون الخليجى، بحث منثـور ، مجلة القاهرة للخدمة الاجتماعية، القاهرة، ا.... T.

37.Vida. Stephen, Monks_Rich and c.:prevalence and correlates of elder abuse and neglection imageriatric psychiatry service, Canadian journal of phycho;iatry, 2002.

1 r.جمال شـكرى محمد عثمان: فاعلية خدمة الفرد الجماعية فى التعامل مع العزلة الاجتماعية للمسنين، المؤتمر العلمى الخامس عشر، كلية الخدمة الاجتماعية، جامعة حلوان، الجزء الأول r ... r.

39.Berger n, o;, Rene Gray Betsey: Ethical Dilem man of reporting suspected elder abuse for social work, 2003. 
• ـ. هيام محمد على: نحو تصــور مقترح لاسـتخدام اخصــائى خدمة الجماعة نموذج التذخل فى الأزمة لمواجهة مشـكلة إسـاءة كبار السـن، بحث منشــور ، مجلة دراســات فى الخدمة الاجتماعية والعلوم الانسانية، كلية الخدمة الاجتماعية، جامعة حلوان، عدد الY، اكتوبر ، ج . . . . اء.رثــاد احمد عبد اللطيف: مدخل التأهيل المرتكز على المجتمع ومواجهة احتياجات المسـنات، بحث منشور ، مؤتمر المرأة المسنة فى العالم العربى الواقع والمأمول، جامعة حلوان، القاهرة، ب. . . .

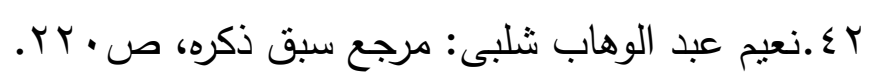
بـ ـ على حســين زيدان وآخرون: نماذج ونظربات معاصــــرة في خدمة الفرد، كلية الخدمة الاجتماعية،

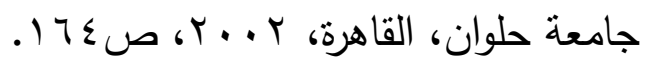


ملاحق الدراسة

ملحق رقم (1) - 20 - (1)

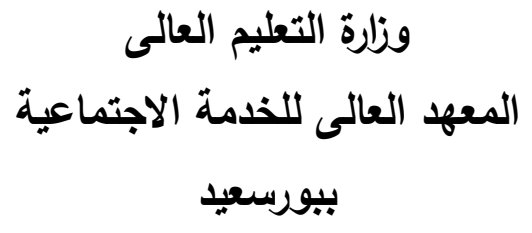

استمارة

قياس فعالية استخدام نموذج الحياة فى تعزيز الدمج الاجتماعى لكبار السن المقيمين بدار ايواء ورعاية كبار السن بمحافظة بورسعيد

\author{
دكثورة \\ داليا نعيم عبد الوهاب شلبى \\ مدرس خدمة الفرد \\ بالمعهد العالى للخدمة الاجتماعية \\ بورسعيا
}

r.r. 
أولاً البيانات المعرفة بالمسن:

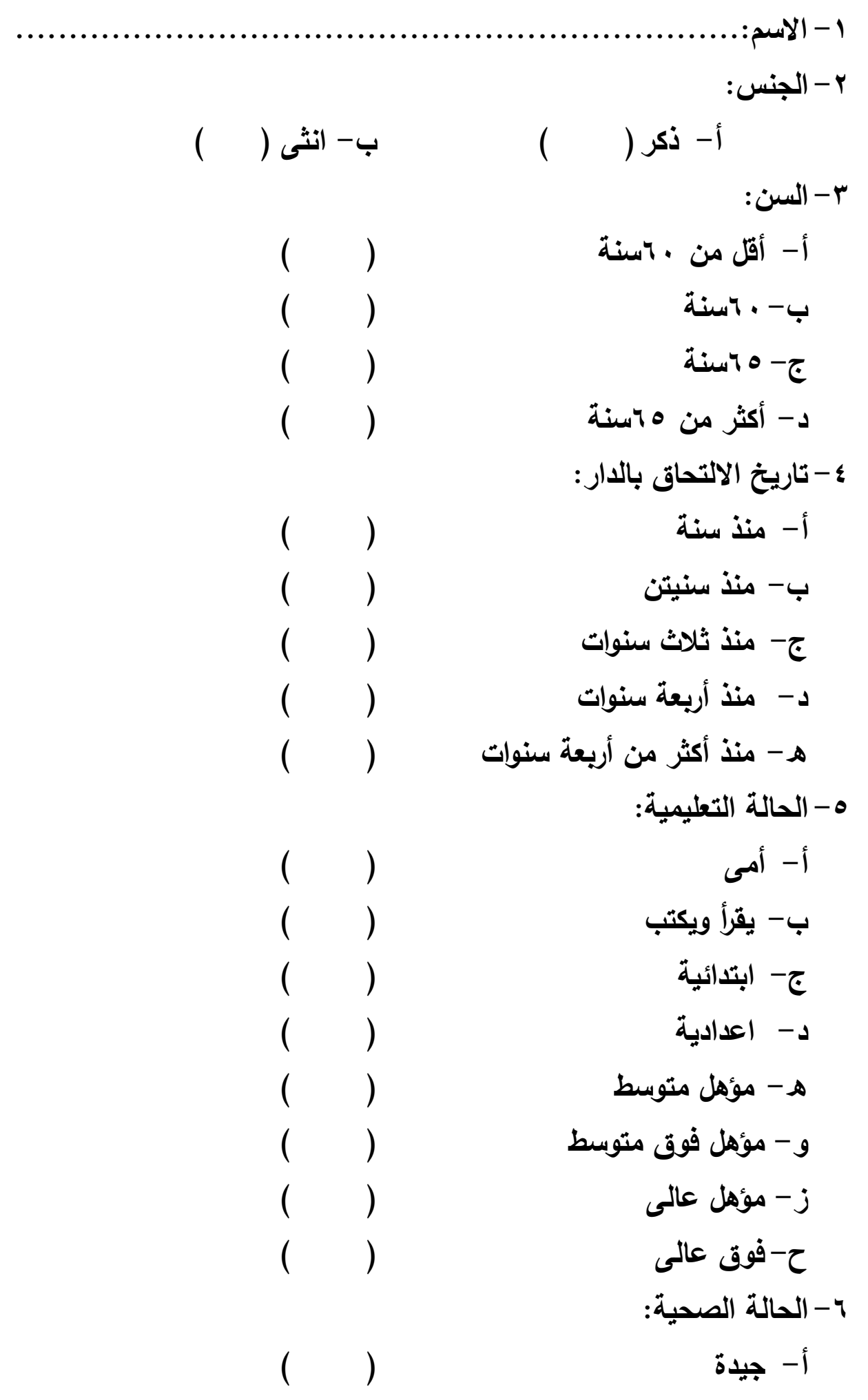




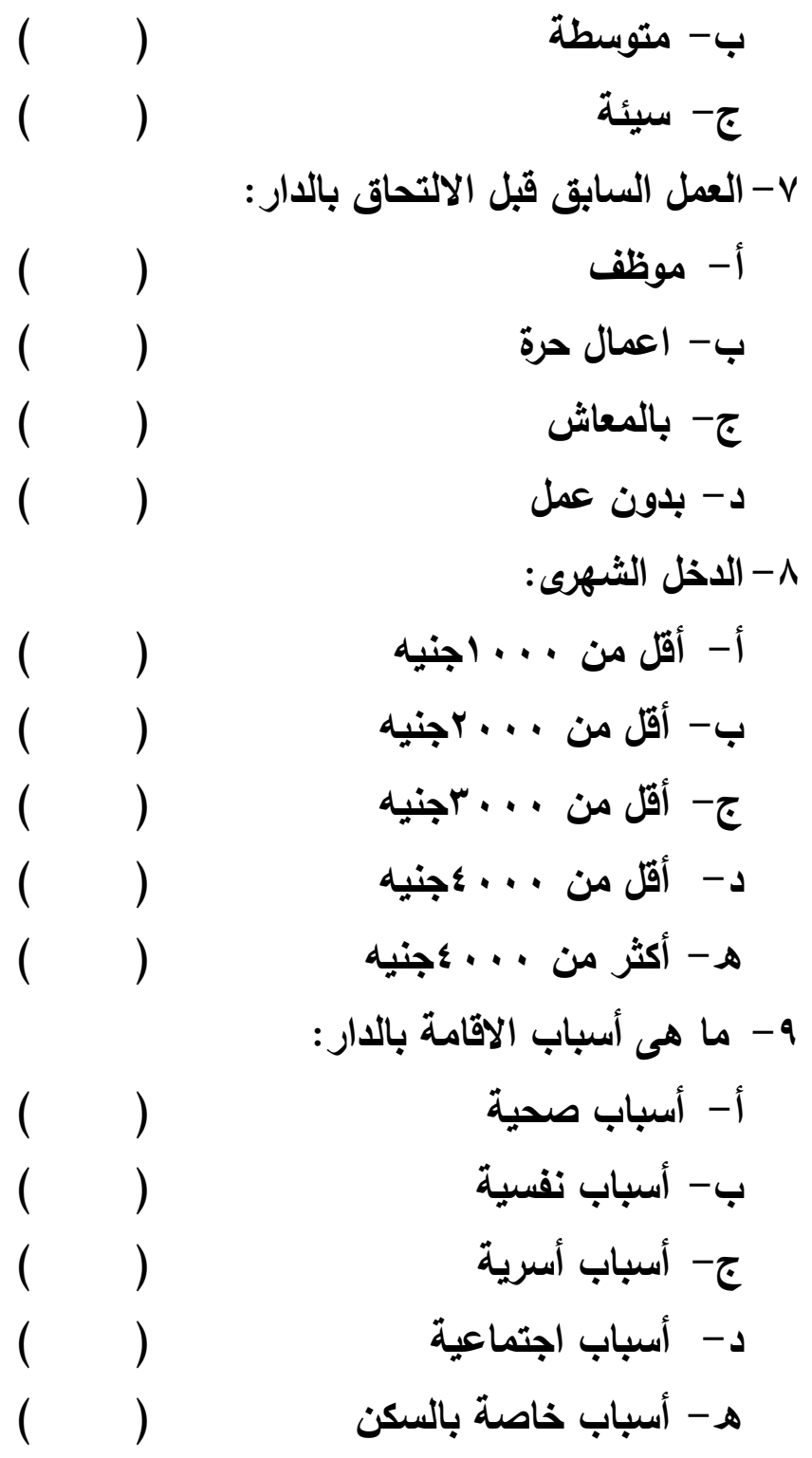

\begin{tabular}{|c|c|c|c|}
\hline نادراً & أحياناً & 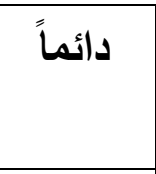 & • 1 - ما هي أوجه الأنثطة والبرامج التى تثارك \\
\hline ) & ) & ) & أ- قراءة القرآن \\
\hline$)$ & ) & ( & ب- قراءة كتب وقصص \\
\hline$)$ & ) & ( & ج- قراءة صحف يومية ومجلات \\
\hline$)$ & ) & ) & د- الاستماع للإذاعة \\
\hline
\end{tabular}




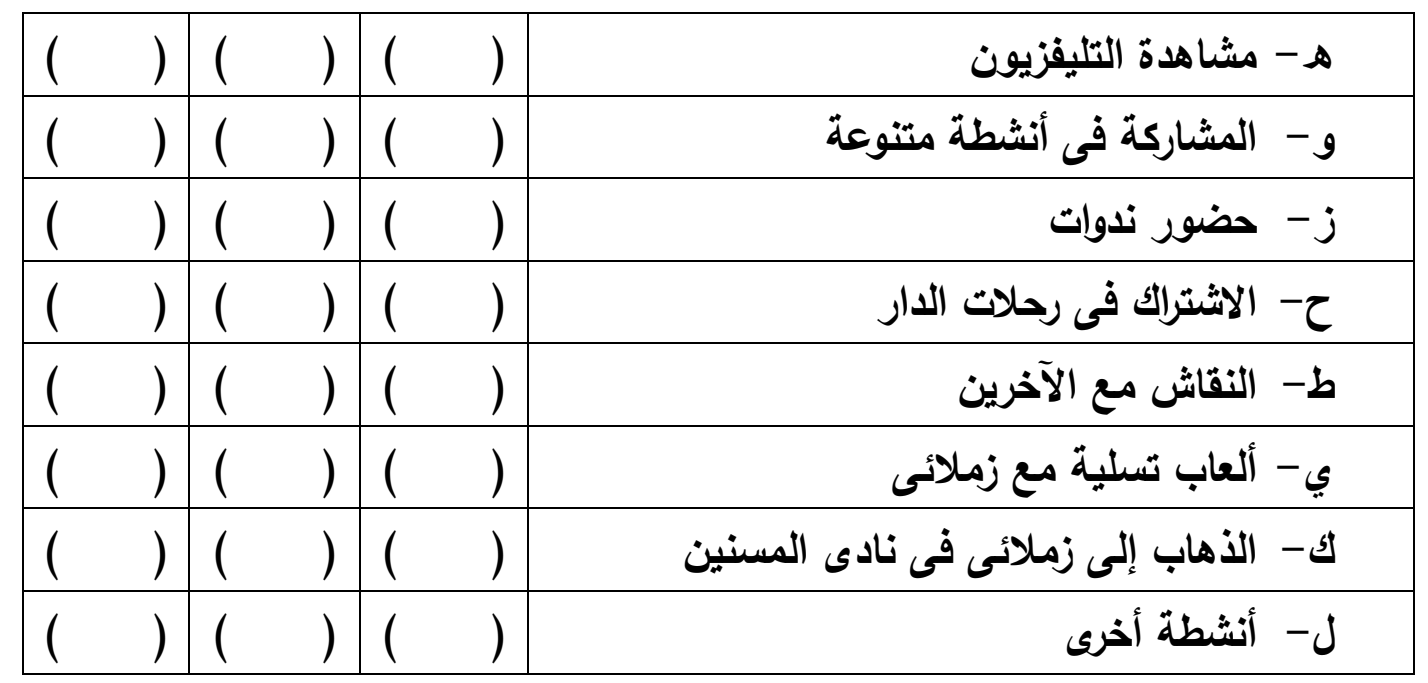

ثانياً: مقياس تعزيز الدمج الاجتماعى لكبار السن:

البعد الأول: الامج الاجتماعى لكبار السن فى محيط الأسرة:

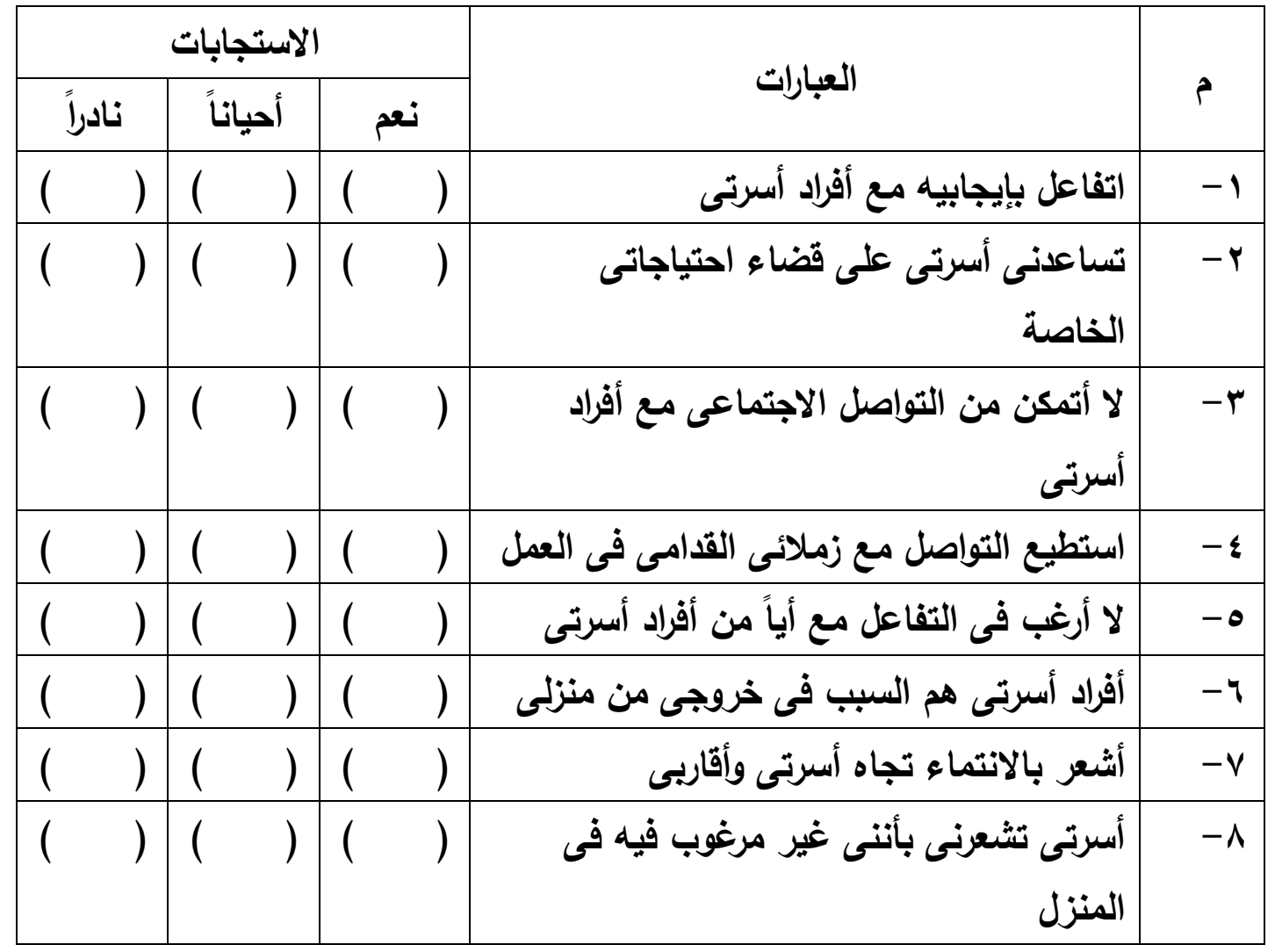




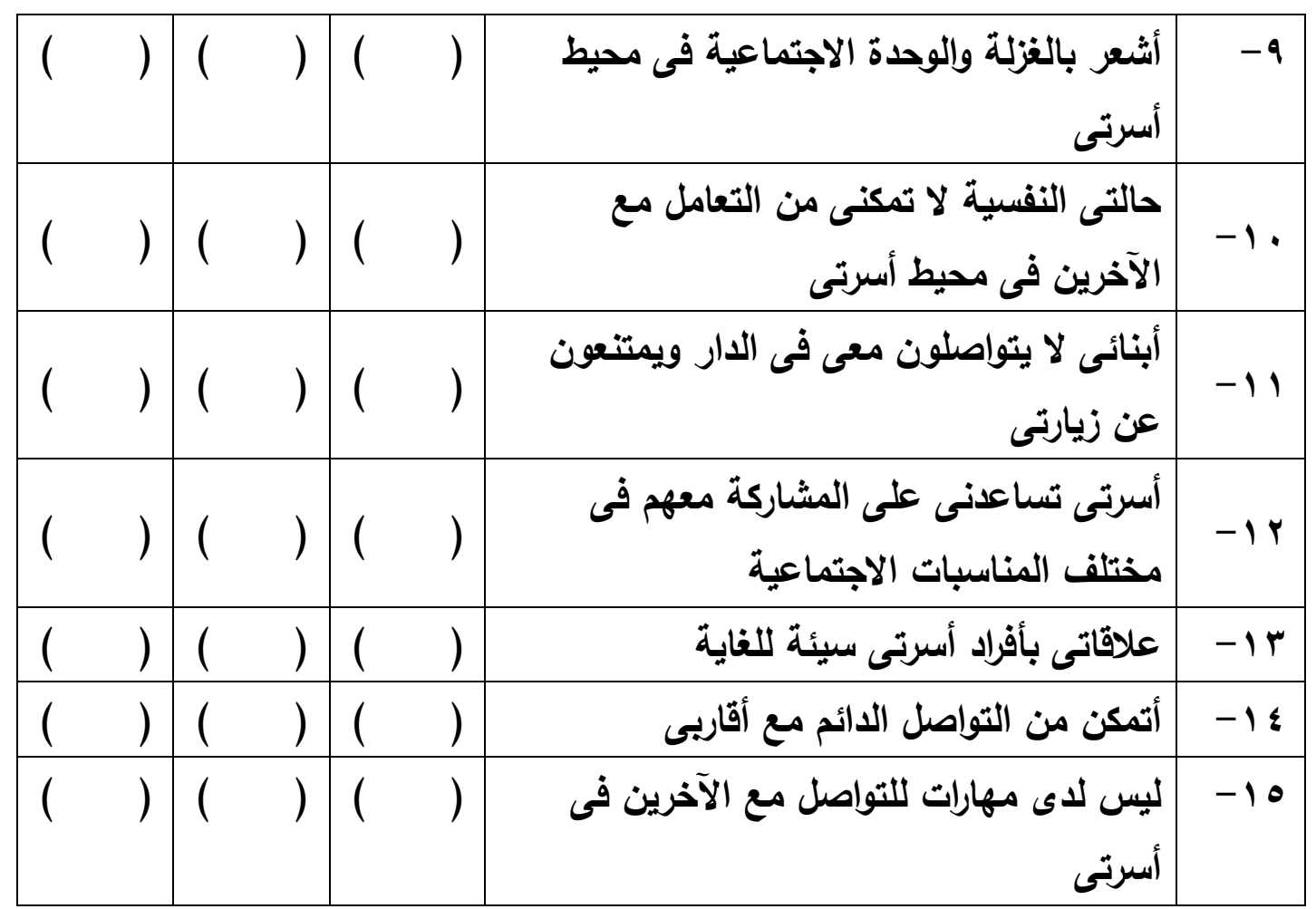

البعد الثانى: الامج الاجتماعى لكبار السن فى مؤسسة الإيواء:

\begin{tabular}{|c|c|c|c|c|}
\hline \multicolumn{3}{|c|}{ الاستجابات } & \multirow{2}{*}{ 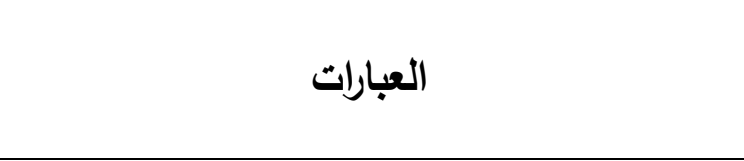 } & \multirow{2}{*}{ b } \\
\hline 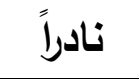 & أحياناً & نعم & & \\
\hline ) & ) & ( & أتمكن من إقامة علاقات مع أقرانى بالمؤسسة & -17 \\
\hline ) & ( & ( & أستطيع إقامة علاقات مع الاداريين بالمؤسسة & $-1 V$ \\
\hline ) & ( & ( & الاجتماعية المؤسسة يشجع على الوحدة والعزلة & -11 \\
\hline ) & ) & ) & لا الاجتماعى من التمؤسول الاجتماعى مع الاخصائى & -19 \\
\hline$)$ & ) & ) & لا أثشارك برامج وأنثطة المؤسسة المختلفة & $-r$. \\
\hline$(\quad)$ & $(\quad)$ & ) & أرغب في حضور المناسبات الاجتماعية داخل & $-r_{1}$ \\
\hline
\end{tabular}




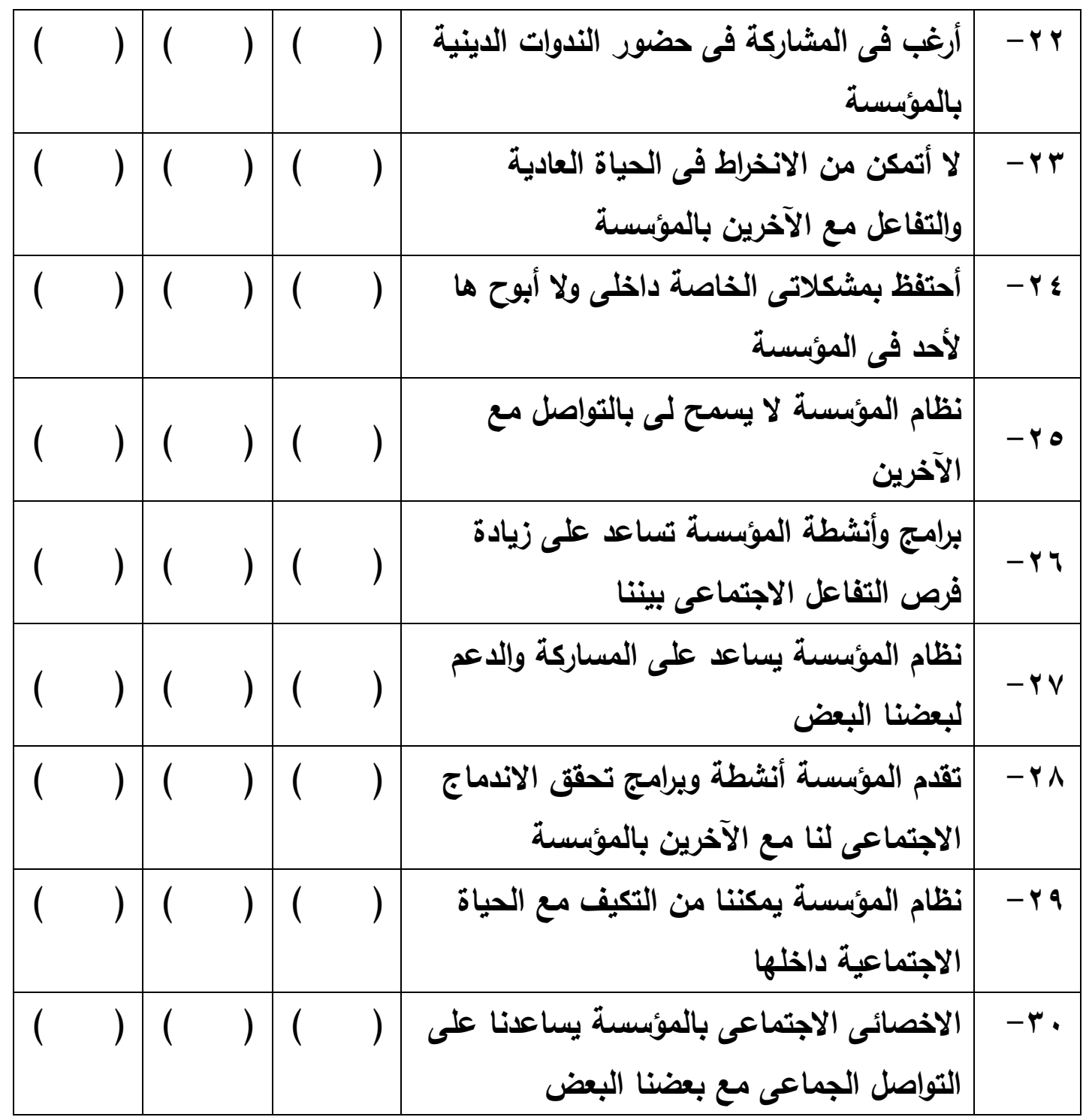

البعد الثالث: الامج الاجتماعى لكبار السن فى المجتمع:

\begin{tabular}{|c|c|c|c|c|}
\hline \multicolumn{3}{|c|}{ الاستجابات } & \multirow{2}{*}{ العبارات } & \multirow[b]{2}{*}{ r } \\
\hline نادراً & أحياناً & نعم & & \\
\hline$(\quad)$ & $(\quad)$ & $(\quad)$ & لجى أن المجتمع يحقق التكافؤ الاجتماعى & ו \\
\hline$(\quad)$ & $(\quad)$ & $(\quad)$ & جحقق المجتمع المساواة بين المسنين فى الاحتياجات المطلوية لهم & $-M r$ \\
\hline
\end{tabular}




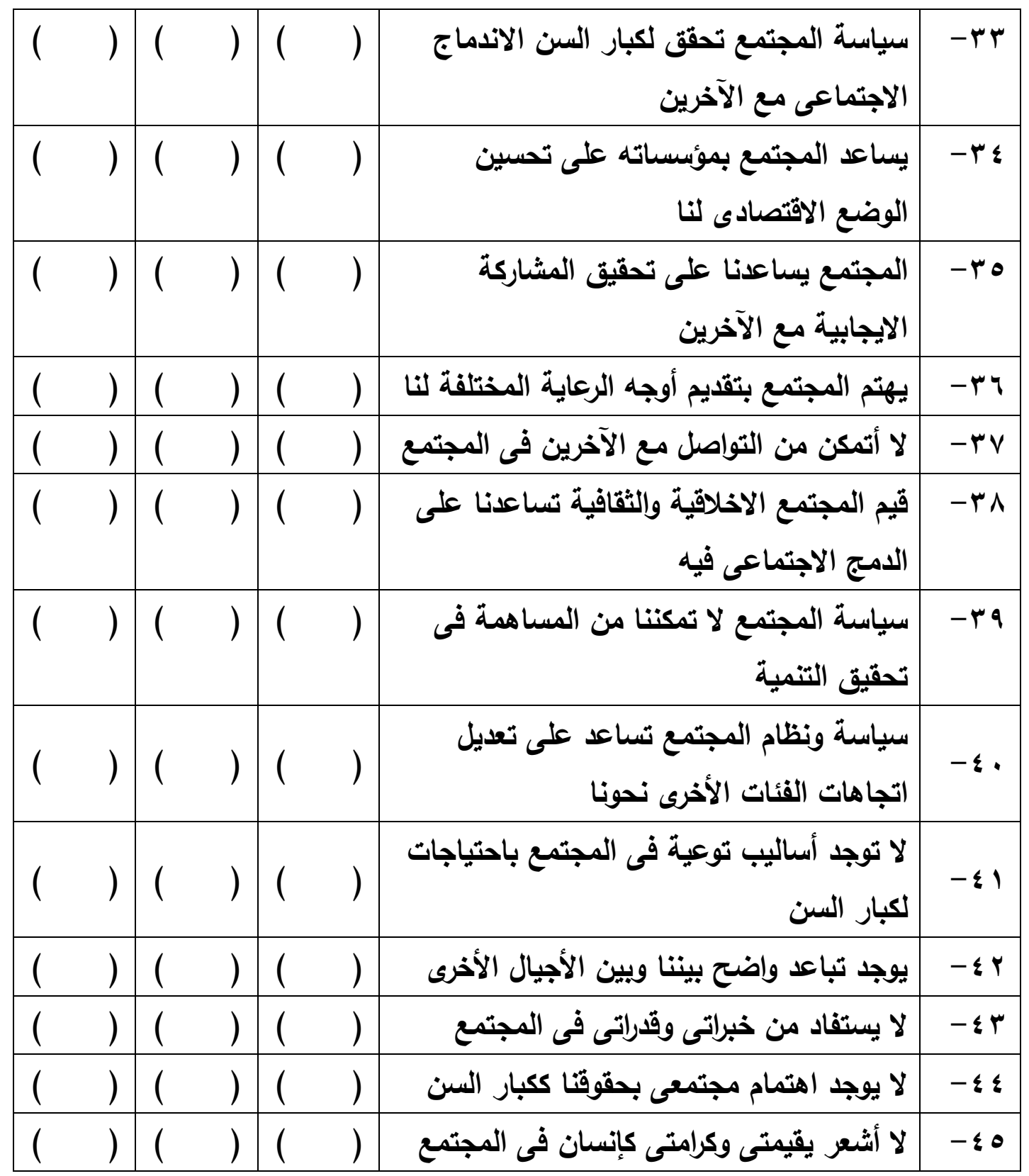


ملحق رقم (r)

أسماء السادة المحكمين لأدوات الدراسة

\begin{tabular}{|c|c|c|}
\hline الوظيفة & الاسم & م \\
\hline الستاذ مجالات الخدمة الاجتماعية- كلية الخدمة & أ.د / مدحت أبو النصر & 1 \\
\hline أستاذ علم التفس ووكيل كلية التريية- جامعة & | أ.د/هشام النرش & $r$ \\
\hline أستاذ علم النفس بكلية التربية النوعية - جامعة & أ.دد/ جمال تفاحة & $r$ \\
\hline أستاذ ورئيس قسم خدمة الفرد - العميد السابق & أ.دد/ نعيم عبد الوهاب شلبى & $\varepsilon$ \\
\hline
\end{tabular}


ملحق رقم(ب)

خطاب من مؤسسة التطبيق الميدانى

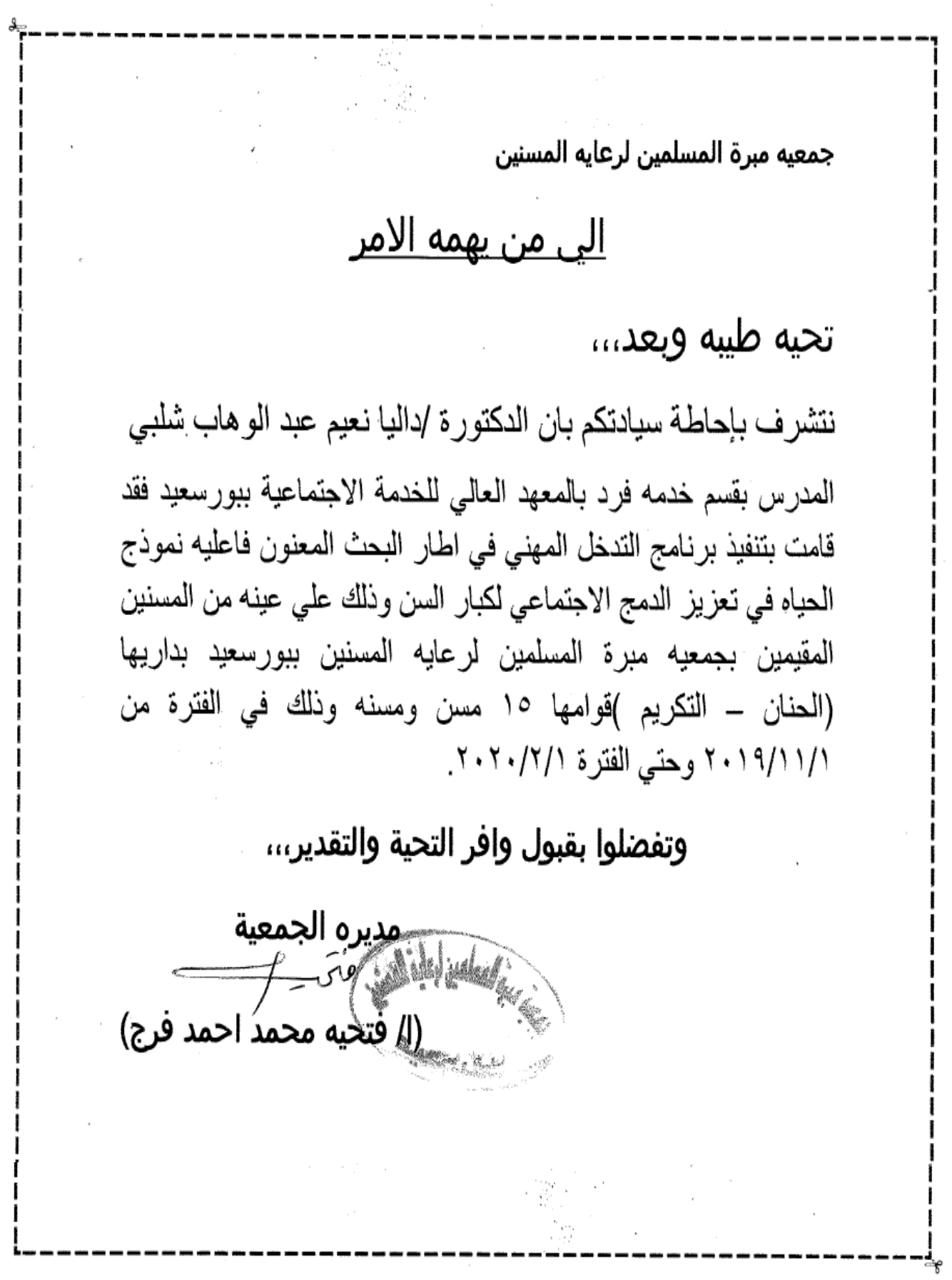


مجلة كلية الخدمة الاجتماعية للار اسات و البحوث الاجتماعية - جامعة الفيوم 